ACTA THERIOLOGICA

Vol. $34,40: 545-593,1989$

\title{
Dental Polymorphism in the Genus Martes (Carnivora: Mustelidae) and Its Evolutionary Significance
}

\author{
Mieczysław WOLSAN ${ }^{1}$
}

\begin{abstract}
Wolsan M., 1989: Dental polymorphism in the genus Martes (Carnivora: Mustelidae) and its evolutionary significance. Acta theriol., 34, 40: 545-593 [With 10 Figs ]

Polymorphisms of $\mathrm{P}_{1}^{1}, \mathrm{P}_{3}^{3}, \mathrm{P}_{4}$, and $\mathrm{M}^{1}$ are described by morphotypes in 28 recent populations of Martes martes $(n=828), M$. martes $\times M$. zibellina $(\mathrm{n}=37), M$. zibellina $(\mathrm{n}=749), M$. melampus $(\mathrm{n}=1), M$. americana $(\mathrm{n}=28), M$. foina $(n=593), M$. flavigula $(n=53)$, and $M$. pennanti $(n=4)$. Both the species and their populations differed qualitatively and quantitatively from each other in the morphotype frequency distributions. Statistically significant sexual dimorphism in frequency distributions of the morphotypes was discovered only for the presence-absence polymorphism of $P_{1}$, with females being more often affected by the congenital tooth loss. The morphotypes occurred either bilaterally or unilaterally, and generally the less frequent a morphotype the greater an amount of the right-left asymmetry. The results indicate that both genetic and environmental factors determine a morphotype. Supporting evidence is presented for a hypothesis that the polymorphous characters are derived from a Late Cretaceous/Early Paleogene eutherian ancestor and that ontogeny in living martens recapitulates the Cenozoic evolution of tooth morphology in the lineage of Martes. A model of the genetic control of evolutionary changes in dental morphology is proposed. According to the model, at an early stage of tooth development, threshold mechanisms connected with size would operate, whereby dental structures reaching the threshold continued to develop, while the others atrophied. Genetic information responsible for the antethreshold morphological pattern would be virtually stable during evolution. A general trend to progressive simplification in the postthreshold pattern of dental morphology would be an effect of gradual changes in frequencies of morphotypes towards the simplest morphologically, resulting from the progressive upward movement of the threshold level and/or the backward movement of the threshold stage. These movements would be caused by qualitative changes in a set of other genes than those of the antethreshold morphological pattern.
\end{abstract}

[Institute of Systematic and Experimental Zoology, Polish Academy of Sciences, Sławkowska 17, 31-016 Kraków, Poland]

\section{INTRODUCTION}

Musteloid carnivores developed in two radiations (Schmidt-Kittler, 1984). The earlier one originated in the Oligocene, with procyonids as living descendants. The second radiation, comprising mustelids, arose with the beginning of the Early Miocene. Both the radiations gave rise

1 Present address: Mammal Research Institute, Polish Academy of Sciences, 17-230 Białowieża, Poland. 
to a great number of lineages, with maximum diversity in the Miocene. The real relationships within musteloids are hidden by a number of parallelisms in their evolution. Moreover, mustelids show a distinct sexual dimorphism in body size (Moors, 1980), which impedes their taxonomic identification.

This paper presents some tooth characters, independent of sex for the most part, which may be helpful in elucidating the phylogeny of mustelids. Attempts were made to reconstruct the evolution of dental morphology in the lineage of Martes during the Cenozoic. Martens were chosen because they seem to be close to the basal stock of mustelids, as indicated by several primitive characters (Anderson, 1970) and occurrence since the Early Miocene (Roth \& Mein, 1987). In addition, a model of the genetic control of evolutionary changes in dental morphology is proposed.

\section{MATERLAL}

The study is based on a survey of permanent dentitions in 2293 recent specimens of the genus Martes Pinel, 1792. The seven species studied include: the European pine marten Martes (Martes) martes (Linnaeus, 1758), the sable $M$. (M.) zibellina (Linnaeus, 1758), the Japanese marten $M$. (M.) melampus (Wagner, 1841), the American pine marten $M$. (M.) americana (Turton, 1806), the stone marten $M$. (M.) foina (Erxleben, 1777), the yellow-throated marten $M$. (Charronia) flavigula (Boddaert, 1785), and the fisher M. (Pekania) pennanti (Erxleben, 1777). The European pine martens came from France $(n=25)$, Austria $(n=60)$, Bohemia $(n=125)$, Moravia $(n=46)$, Slovakia $(n=43)$, Poland $(n=230)$, northern part of the European USSR $(n=127$; Novgorodskaya Oblast', Leningradskaya Oblast', Finno-Karelian ASSR, Arkhangel'skaya Oblast'), central part of the European USSR $(n=47$; Moskovskaya Oblast'), Ukraine $(n=25)$, Caucasus Mts region ( $n=90$; Kuban' region, Caucasus Mts, Georgian SSR), and Ural Mts region ( $n=10$; Bashkir ASSR). The sables were caught in the Ural Mts region ( $n=150$; Ural'skaya Oblast', Permskaya Oblast', Pechoro-Ilychskiy Nature Reserve, Kondo-Sos'vinskiy Nature Reserve), central Asia ( $n=238$; USSR: Irtysh region, Altai, Sayan, Krasnoyarskiy Kray, Irkutskaya Oblast', Buryat-Mongol ASSR), Kamchatka $(n=306)$, and Far East $(n=55$; USSR: Amurskaya Oblast', Khabarovskiy Kray, Primorskiy Kray, Sakhalin). The single Japanese marten involved Japan and the American pine martens referred to the Alaska and Montana populations $(n=28)$. The stone martens came from France $(n=68)$, Austria $(n=52)$, Bohemia $(n=138)$, Moravia $(n=125)$, Poland $(n=57)$, Ukraine $(n=56)$, Caucasus Mts region $(n=84$; Caucasus Mts, Georgian SSR, Azerbaidzhan SSR, Armenian SSR), and central Asia ( $n=13$; Kopet Dagh, Pamirs, Tien Shan, Altai, Mongolia). The yellow-throated martens were hunted in the Far East of the USSR ( $n=53$; Primorskiy Kray), whereas the fishers were from Manitoba and Montana $(n=4)$. In addition, 37 specimens of the hybrid $M$. martes $\times M$. zibellina from the Ural Mts region (Pechoro-Ilychskiy Nature Reserve) were available.

The specimens examined belong to the collections of the Mammal Research Institute, Polish Academy of Sciences, Bialowieza; the Institute of Systematic and Ecological Biology, Czechoslovak Academy of Sciences, Brno; the Moravian Museum, Brno; the Institute of Systematic and Experimental Zoology, Polish Academy of Sciences, Cracow; the Institute of Animal Biology, University of Dijon; the Institute of Zoology, Academy of 
Sciences of the Ukrainian SSR, Kiev; the Zoological Institute, Academy of Sciences of the USSR, Leningrad; the Guimet Museum of Natural History, Lyon; the Department of Earth Sciences, C. Bernard University, Lyon; the Zoological Museum, Moscow State University; the Laboratory of Mammal and Bird Zoology and the Laboratory of Comparative Anatomy, National Museum of Natural History, Paris; the Laboratory of Vertebrate and Human Palaeontology, P. \& M. Curie University, Paris; the Department of Systematic Zoology, A. Mickiewicz University, Poznan; the Institute of Systematic Zoology, Charles University, Prague; the National Museum (Natural History), Prague; the Natural History Museum, Vienna; and to the private collection of Dr. A. L. Ruprecht, Białowieża.

The material examined by Wolsan et al. (1985) and Wolsan (1988) was included.

\section{METHODS}

To describe the dental polymorphism, seven groups of morphotypes were distinguished. Group A (Wolsan et al., 1985) deals with $\mathbf{P}^{3}$. Variation in this tooth is manifested by the occurrence of morphological patterns representing transitional stages from three to two roots, accompanied by gradual changes in the base of crown (Fig. 1):

Al - two roots, no concavity in the lingual contour of the crown in occlusal view;

A2 - two roots, the posterolingual contour of the crown is concave in occlusal view;

A3 - two roots, a concavity is visible both in the posterior and in the anterior part of the lingual contour of the crown in occlusal view;

A4 - three roots, with the smallest one placed lingually; the posterolingual and anterolingual contour concavities are distinet in occlusal view.

The morphotypes of group B (Wolsan et al., 1985) describe the polymorphisms of $P_{3}$ and $P_{4}$. They consist in the occurrence of morphological patterns representing transitional stages from a small but distinct cusp on the posterior ridge of the protoconid to no trace of the cusp (Fig. 2):

$B 1$ - the posterior ridge of the protoconid without any convexity;

B2 - the posterior slope of the protoconid with a small elevation passing smoothly into the ridge;

B3 - the posterior slope of the protoconid shows a small elevation which passes anteriorly into the ridge at a right angle;

B4 - the posterior slope of the protoconid exhibits a cusp-like elevation separated anteriorly from the ridge by a shallow occlusobasal $V$-shaped indentation;

B5 - the posterior slope of the protoconid bears a small but distinct cusp separated anteriorly from the ridge by a clear $\mathrm{V}$ - or U-shaped occlusobasal depression.

The morphotypes of group $\mathrm{C}$ (Wolsan et al., 1985) describe variation in the posterobuccal part of $\mathrm{M}^{\mathbf{1}}$, consisting in the occurrence of morphological patterns which represent transitional stages from a distinct $V$-shaped indentation in the contour of the cingulum to no trace of any concavity, accompanied by gradual changes in the size of the metacone and posterobuccal root (Fig. 3):

$\mathrm{Cl}$ - no concavity in the contour of the posterobuccal cingulum, the metacone and posterobuccal root are smail;

$\mathrm{C} 2$ - the posterobuccal contour of the cingulum is slightly concave, the metacone and posterobuccal root are intermediate in size as compared with those in morphotypes $\mathrm{Cl}$ and $\mathrm{C} 3$;

$\mathrm{C} 3$ - the posterobuccal contour of the crown shows a distinct $\mathrm{V}$-shaped indentation in occlusal view, the metacone and posterobuccal root are large.

Group D (Wolsan, 1988) deals with the posterolingual part of $\mathrm{M}^{1}$. The polymorphism of this crown region consists in the occurrence of some accessory elevations of the en- 
amel surface. These elevations form minor ridges and cuspules of variable size and form, developed along two curves branching from the posterior part of the medial ridge (which runs posterolingually from the anteromedial cingulum) and crossing the posterolingual part of the occlusal surface to reach the posterior cingulum. The three regions were distinguished both in the buccal and in the lingual curve: the anterior (designated $a$ and $d$, respectively), medial ( $b$ and $e$ ), and posterior ( $c$ and $f$ ). The morphotypes were named according to the designation of the curve regions in which the elevations occurred. The absence of any elevation was termed D- (Fig. 4).

Group E (Wolsan, 1988) deals with the ridge which runs posterolingually from the anteromedial cingulum of $M^{1}$. Variation in this ridge is manifested by the occurrence of morphological patterns representing transitional stages from a deep occlusobasal depression in about half of the ridge length to no trace of any concavity (Fig. 6):

E1 - the ridge without any concavity;

E2 - the ridge exhibits a V- or U-shaped occlusobasal depression in about half of the length.

The morphotypes of groups $F$ and $G$ describe the presence-absence polymorphisms of $P^{1}$ and $P_{1}$, respectively:

$F 1(G 1)-P^{1}\left(P_{1}\right)$ is present;

F2 (G2) $-P^{1}\left(P_{1}\right)$ is congenitally absent.

Both the left and the right teeth of each specimen were included in morphotype counting because of a frequent asymmetric occurrence of the morphotypes. If the number of scored teeth $(\mathbb{N})$ given in figures is smaller than twice as many as the corresponding number of skulls ( $n$ ), it was caused by missing teeth, heavy wear, or abnormal tooth development which prevent the definite determination of a morphotype.

The absence of $P_{1}^{1}$ was noted only when there was no sign of its prior presence in dentition, that is when there was neither socket nor any trace of its overgrowing. Teeth in carnivores, particularly the smallest ones in the postcanine tooth row, tend to be lost during an animal's life and their sockets to be overgrown. Hence, the older a carnivore the more probable it becomes to recognize incorrectly a tooth deficiency as congenital. To minimize the number of misinterpretations, the old specimens were left out of account.

\section{RESULTS}

The absolute and percentage frequency distributions of the morphotypes of groups A-G in the populations are presented in Figs 1-4 and 6-8. For the frequency distributions of enamel elevations a-f see Fig. 5. When the absolute frequency distributions for females and males were compared by the chi-square test, significant differences $(p<0.05)$ occurred only for the morphotypes of group G (Fig. 8). The same morphotype affects either both body sides or one side only, and generally the less frequent a morphotype the greater an amount of the right-left asymmetry (Figs 1-8).

\section{DISCUSSION}

\section{1. Ontogeny}

The features of polymorphisms A-G clearly fit the criteria of quasi-continuous variation which is believed to be due to threshold effects 
(Glass \& Todd, 1977). Threshold mechanisms would operate at an early stage of ontogeny. Those elements of a structure which reached the threshold at the critical stage of development would continue to develop, while the others would fail to develop any further. Therefore, for thresholds connected with size, the smaller a developing structure the more likely it is to atrophy. Consequently, the more frequent a tooth structure in completely developed dentitions the more probable it was for it to be well developed at the threshold stage. Thus, employing polymorphisms A-G and frequency distributions of the morphotypes and elevations a-f, it seems possible to reconstruct a highly probable morphological pattern of the involved tooth regions before and at the threshold stage (Wolsan, 1988).

And so, it seems very probable that the antethreshold morphological pattern of $\mathrm{P}^{3}$ in Martes corresponds to morphotype A4, showing buds of the three roots, with the smallest one placed lingually, and a distinct concavity in the anterior and posterior parts of the lingual contour of the cingulum homologue. During the postthreshold stage, according to the size of the lingual root bud at the threshold stage and to the threshold level, the bud would continue to develop, remaining as a separate root in a completely developed tooth (morphotype A4) or it would fail to develop, fusing partially (A3 and A2) or entirely (A1) with the posterior root. Progressive reduction in the size of the lingual root would be accompanied by simultaneous simplification in the shape of the lingual contour of the cingulum, with the posterior concavity persisting longer than the anterior one.

For $\mathrm{P}_{3}$ and $\mathrm{P}_{4}$ in Martes, the posterior slope of the protoconid bud most likely bears a small cusp at the antethreshold stage, resembling morphotype B5. According to the size of this cusp at the threshold stage and to the threshold level, the cusp would continue to develop during the postthreshold stage, remaining as a small but distinct cusp in a completely developed tooth (morphotype B5), or it would fail to develop, fusing partially (B4-B2) or entirely (B1) with the posterior ridge of the protoconid.

At the antethreshold stage of the $\mathrm{M}^{1}$ ontogeny in Martes, in all likelihood, the buds of the metacone and posterobuccal root are relatively large and the posterobuccal contour of the cingulum homologue shows a distinct indentation, corresponding to morphotype C3. During the postthreshold stage, according to the size of the buds of the metacone and posterobuccal root at the threshold stage and also to the threshold level, these buds would continue to develop, resulting in morphotype C3, or they would undergo a gradual size reduction as compared to other elements of a developing tooth germ (C2 and C1). Progressive re- 
duction in the size of the metacone and posterobuccal root would be accompanied by simultaneous simplification in the shape of the posterobuccal contour of the cingulum.

The topography of the $\mathrm{M}^{1}$ crown in completely developed marten dentitions suggests that the antethreshold morphological pattern of the tooth shows the three ridges on the occlusal surface: the posterobuccal, posterolingual, and anterobuccal, corresponding, respectively, to the complete elevations abc and def and the ridge which runs from the medial part of the anterior cingulum to the centre of the lingual part of the crown. Some portions of the three ridges would be strongly developed, some others, poorly, resulting in the occurrence of swellings and depressions, respectively. The swellings, usually cusp-like, would occur in the anterior and posterior parts of the anterobuccal ridge and also in the $c$ and e regions, whereas the depressions would occupy the medial part of the anterobuccal ridge and the $b$ and $d$ regions (valleys) and also regions a and $f$ (slopes), as indicated by the shape and frequencies of elevations a- $f$ and by polymorphism $E$. Thus, the antethreshold pattern would refer to morphotypes Dabcdef and E2. According to the size of the three ridges at the threshold stage and to the threshold level, some portions of the ridges would continue to develop during the postthreshold stage, while some others would fail to develop, resulting in polymorphisms $\mathrm{D}$ and $\mathrm{E}$ in completely developed dentitions (Wolsan, 1988).

In all probability, the germs of $P^{l}$ and $P_{1}$ are present at the antethreshold stage of dental ontogeny in Martes. According to the size of these germs at the threshold stage and to the threshold level, the germs would continue to develop during the postthreshold stage, occurring in completely developed dentitions (morphotypes F1 and G1), or they would fail to develop, resulting in morphotypes F2 and G2. Marten teeth are generally smaller in females than in males (Wolsan et al., 1985), which is presumably also true for the tooth germs. This would account for the higher frequency of the congenital deficiencies of $\mathrm{P}_{1}^{1}$ in females (Fig. 8).

\section{2. Etiology}

The morphological variations studied show an evident regularity with respect to the site of appearance and the form. For instance, the enamel elevations essential for the non-D-morphotypes were developed exactly along two curves of constant route, with a cusp-like elevation frequent in curve regions $c$ and $e$ and some enamel ridges or banks predominant in the other regions (Fig. 4).

The extant marten species, of the subgenus Martes in particular, 
show the same patterns of dental variability. The species differ each other in frequency distributions of the morphotypes. The differences, though expressed to a lesser degree, exist also at the population level. A geographical distribution of the morphotype frequencies shows an obvious clinal pattern in some instances. For example, the E2 frequency in $M$. martes usually decreases with the distance from Slovakia (Fig. 6).

Finally, the morphotype frequency distributions for the Ural Mts population of the hybrid $M$. martes $\times M$. zibellina are generally of a clear transitional pattern as compared with those for the sympatric populations of $M$. martes and $M$. zibellina. For instance, the E1 frequencies are $39 \%, 79 \%$, and $8 \%$, respectively (Fig. 6).

All the facts mentioned above indicate that the morphological characters involved in polymorphisms A-G are hereditary. Genetic information would be responsible for the antethreshold morphological pattern, the height of the threshold, and the location of the threshold event in ontogeny. The amount of the right-left asymmetry in occurrence of the morphotypes suggests that apart from genetic influences, also some environmental ones are important in determining the final morphological pattern. It seems, however, that non-genetic factors produce only slight movements of the threshold leyel and threshold stage (Wolsan, 1988).

\section{3. Evolution}

Because polymorphisms A-G are evidently under a strong genetic control, there are two possible explanations for their presence in the recent members of the genus Martes. The first explanation would be that the polymorphous characters are derived from a Late Cretaceous/Early Paleogene eutherian ancestor. The second explanation would imply that these characters are determined by genes which originated as a result of some relatively recent mutations; then they would be analogous to or apomorphous with respect to the corresponding characters in early eutherian mammals (Wolsan, 1988).

Polymorphisms A-G affect all the extant marten species, which suggests that they are inherited from their common ancestor. It seems to be unlikely that we are dealing with a homoplastic similarity. That patristic characters are concerned is supported by paleontological evidence. Morphotypes A1-A3, B1-B3 for $\mathrm{P}_{3}, \mathrm{~B} 3-\mathrm{B} 5$ for $\mathrm{P}_{4}, \mathrm{C} 1-\mathrm{C} 3, \mathrm{D}-, \mathrm{E} 1$ or E2, F1, and $\mathrm{G} 1$ prevail in the living species of Martes, which was presumably also true for other Quaternary members of this genus (Heller, 1933; Dehm, 1962; Anderson, 1970; Rabeder, 1976). The preserved remains of Neogene martens suggest that morphotypes A3, B2 
and B3 $\left(\mathrm{P}_{3}\right), \mathrm{B} 4$ and B5 $\left(\mathrm{P}_{4}\right), \mathrm{C} 3, \mathrm{Dabc}$ and Dac, E2, F1, and $\mathrm{G} 1$ belonged to the commonest ones within groups A-G during the Neogene (Gaillard, 1899; Viret, 1933; Dehm, 1950; Ginsburg, 1961, 1977; Petter, 1967a, 1971; Ginsburg \& Bulot, 1982; Wolsan et al., 1985; Wolsan, 1988). In the holotype specimen of the Early Miocene Paragale huerzeleri Petter, 1967, one of the oldest known mustelids (Schmidt-Kittler, 1981), $M^{1}$ resembles morphotype Dabcdef in morphology (Petter, 1967b).

Furthermore, the dental morphological patterns in some eutherian mammals from the Late Cretaceous and Early Paleogene (Vandebroek, 1961) were strikingly congruent with those extrapolated for the antethreshold stage of dental ontogeny in modern martens. And so, $\mathrm{P}^{3}$ in the early eutherians usually had the three roots: the anterior, posterior, and lingual, and the contour of its cingulum was triangular with rounded vertices and concave lingual sides, as in morphotype $A 4 ; P_{3}$ and $\mathrm{P}_{4}$ generally bore a small cusp on the posterior slope of the protoconid (morphotype B5). The characteristic feature of these mammals was the presence of four premolars in each jaw quadrant, involving morphotypes $\mathrm{F} 1$ and $\mathrm{G} 1$, and the tribosphenic molar morphology. The occlusal surface of the upper tribosphenic molar (Fig. 9) showed the three major cusps: the anterobuccal (paracone), posterobuccal (metacone), and lingual (protocone), which were connected each other by a crest or ridge. The paracone-protocone and metacone-protocone crests formed a minor cusp in about half of their lengths: the paraconule and metaconule, respectively. These cuspules were additionally joined by a short crest with, respectively, the anteromedial and posteromedial parts of the cingulum. Sometimes, there was also a cusp (hypocone) in the posterolingual part of the crown. It might have been united by a crest with the protocone and/or the posterior cingulum. In addition, a distinct indentation often occurred in the contour of the cingulum between the paracone and metacone, as in morphotype C3. The anterior cingulum-paraconule-protocone crest of the tribosphenic molar would correspond to the ridge which runs from the anteromedial cingulum to the centre of the occlusal surface of the $\mathrm{M}^{1}$ crown in recent martens, with a depression separating the paraconule and protocone as a counterpart of that essential for morphotype E2. The protocone-metaconule-posterior cingulum crest would conform with the complete abc enamel elevation, with the posterior protocone slope, the depression between the protocone and metaconule, and the metaconule with its posterior crest as equivalents of elevations $a, b$, and c, respectively. Finally, the protocone-hypocone-posterior cingulum crest would refer to the complete def enamel elevation, with the anterior hypocone crest, 
the hypocone, and its posterior crest corresponding to elevations d, e, and $f$, respectively (Wolsan, 1988).

Thus, the paleontological evidence supports the idea that the morphological characters involved in polymorphisms $A-G$ are derived from some Late Cretaceous/Early Paleogene eutherians. It seems that there is only little probability for morphological patterns as complex as that of the upper tribosphenic molar to originate independently twice in evolution (Wolsan, 1988).

The paleontological data indicate that polymorphisms $A-G$ were characteristic of the extinct marten species, too (Wolsan et al., 1985), which was probably also true for their ancestors, including those of the Late Cretaceous and Early Paleogene. This would suggest that the dental ontogenetic mechanisms in early eutherian ancestors of the lineage of Martes were the same as or similar to those in their living descendants. Therefore, genetic information responsible for the antethreshold morphological pattern of the tooth regions studied would not be a subject to a significant change during the Cenozoic evolution of the marten lineage. A general trend to progressive simplification in the morphological pattern of dentition in the lineage of Martes would be an effect of gradual changes in frequencies of the morphotypes towards the simplest in morphology, namely from A4 through A3 and A2 to $\mathrm{A} 1$, from $\mathrm{B} 5$ through $\mathrm{B} 4, \mathrm{~B} 3$ and $\mathrm{B} 2$ to $\mathrm{B} 1$, from $\mathrm{C} 3$ through $\mathrm{C} 2$ to C1, from Dabcdef through Dabcde, Dabce, Dabc, Dac and Dc to D(Fig. 9), from E2 to E1, from F1 to F2, and from G1 to G2 (Wolsan et $a l ., 1985$; Wolsan, 1988). The gradual changes in the morphotype frequencies would result from the progressive upward movement of the threshold level and/or the backward movement of the threshold stage (Fig. 10). These movements would be caused by qualitative changes in a set of other genes than those of the antethreshold morphological pattern. The former would constitute a significant part in a hierarchic set of the genes of Butler's (1939) morphogenetic field.

The model of the genetic control of evolutionary changes in dental morphology proposed above explains their gradation and directness and the positive correlation between the size of a tooth and the complexity of its morphological pattern both for teeth within the same tooth row and for the homologous teeth of closely related species. It also accounts for a great potential adaptability of mammalian dentitions, which is manifested by dental polymorphism, and for the occurrence of rare morphological variants that are often erroneously called atavisms or anomalies.

Acknowledgments: My sincere thanks go to Dr Henryk Kubiak (Cracow) who supervised this study and gave me valuable advice and assistance throughout every phase of 
it. I am grateful to Prof. Dr P. M. Butler (Egham), Prof. Dr Z. Kielan-Jaworowska (Oslo), Prof. Dr K. Kowalski (Cracow), Prof. Dr Z. Pucek (Białowieża), Prof. Dr D. E. Russell (Paris), Prof. Dr N. Schmidt-Kittler (Mainz), and Prof. Dr H. Szarski (Cracow), for their valuable reviews. For permission to study collections in their care, I wish to express my deep appreciation to Dr M. Andera (Prague), Dr G. F. Baryshnikov (Leningrad), Dr K. Bauer (Vienna), Prof. Dr M. Beiger (Poznañ), Dr I. Herán (Prague), Dr M. Hugueney (Lyon), Dr B. Lange-Badré (Paris), Dr J. Pagés (Dijon), Dr F. Petter (Paris), Mr M. Philippe (Lyon), Dr A. Prieur (Lyon), Prof. Dr Z. Pucek (Białowieża), Dr D. Robineau (Paris), Dr O. L. Rossolimo (Moscow), Dr A. L. Ruprecht (Białowieża), Dr L. Seitl (Brno), Dr O. Stèrba (Brno), Prof. Dr W. A. Topachevskiy (Kiev), and Dr V. Vohralik (Prague).

\section{REFERENCES}

1. Anderson E., 1970: Quaternary evolution of the genus Martes (Carnivora, Mustelidae). Acta Zool. Fenn., 130: 1-132.

2. Butler P. M., 1939: Studies of the mammalian dentitions. - Differentiation of the post-canine dentition. Proc. Zool. Soc. Lond. (B), 1939: 1-36.

3. Dehm R., 1950: Die Raubtiere aus dem Mittel-Miocän (Burdigalium) von Wintershof-West bei Eichstätt in Bayern. Abh. Bayer. Akad. Wiss., Math.-Naturwiss. Kl., N. F., 58: 1-141.

4. Dehm R., 1962: Altpleistocäne Säuger von Schernfeld bei Eichstätt in Bayern. Mitt. Bayer. Staatssamml. Paläont. Hist. Geol., 2: 17-61.

5. Gaillard C., 1899: Mammifères miocènes nouveaux ou peu connus de la Grive-Saint-Alban (Isère). Arch. Mus. Hist. Nat. Lyon, 7 (2): 1-79.

6. Ginsburg L., 1961: La faune des Carnivores miocènes de Sansan (Gers). Mém. Mus. Nat. Hist. Nat. (C), N. S., 9: 1-190.

7. Ginsburg L., 1977: Les Carnivores du miocène de Beni Mellal (Maroc). Géol. Méditerran., 4: 225-239.

8. Ginsburg L. \& Bulot C., 1982: Les Carnivores du miocène de Bezian pres de la Romieu (Gers, France). Proc. Kon. Nederl. Akad. Wet. (B), 85: 53-76.

9. Glass G. E. \& Todd N. B., 1977: Quasi-continuous variation of the second upper premolar in Felis bengalensis Kerr, 1792 and its significance for some fossil lynxes. Z. Säugetierk., 42: 36-44.

10. Heller F., 1933: Ein Nachtrag zur Forest-Bed-Fauna aus der Sackdillinger Höhle (Oberpfalz). Zentralbl. Min. Geol. Palāont. (B), 1933: 60-68.

11. Moors P. J., 1980: Sexual dimorphism in the body size of mustelids (Mammalia: Carnivora): the role of food habits and breeding systems. Oikos, 34: 147-158.

12. Petter G., 1967a: Mustélidés nouveaux du Vallésien de Catalogne. Ann. Paléont. (Vertébrés), 53: 93-113.

13. Petter G., 1967b: Paragale hürzeleri nov. gen., nov. sp. Mustélidé nouveau de l'Aquitanien de l'Allier. Bull. Soc. Geol. France (7), 9:19-23.

14. Petter G., 1971: Origine, phylogénie et systématique des blaireaux. Mammalia, 35 : $567-597$.

15. Rabeder G., 1976: Die Carnivoren (Mammalia) aus dem Altpleistozän von Deutsch-Altenburg 2. Mit Beiträgen zur Systematik einiger Musteliden und Caniden. Beittr. Paläont. Österr., 1: 5-119.

16. Roth C. \& Mein P., 1987: Martes collongensis n. sp. aus der miozänen Fundstelle Vieux-Collonges (Dépt. Rhône, Frankreich). Mainz. Geowiss. Mitt., 16: 157-164.

17. Schmidt-Kittler N., 1981: Zur Stammesgeschichte der marderverwandten Raubtiergruppen (Musteloidea, Carnivora). Ecl. Geol. Helv., 74: 753-801. 
18. Schmidt-Kittler N., 1984: On the phylogenetic and biogeographic history of the musteloid camivores in east and southeast Asia. [In: "The evolution of the east Asian environment, 2." R. O. Whyte, ed.]. Univ. Hong Kong: 710 -723 . Hong Kong.

19. Vandebroek G., 1961: The comparative anatomy of the teeth of lower and non specialized mammals. Int. Coll. Evol. Lower Non Specialized Mammals (Brussel 1960), 1: 215-320, 2: $1-181$.

20. Viret J., 1933: Contribution à l'étude des Carnassiers miocènes de la Grive-Saint-Alban (Isère). Trav. Lab. Geol. Fac. Sci. Lyon, 21 (18): 1-37.

21. Wolsan M., 1988: Morphological variations of the first upper molar in the genus Martes (Carnivora, Mustelidae). [In: "Teeth revisited: proceedings of the VIIth International Symposium on Dental Morphology, Paris 1986." D. E. Russell, J. -P. Santoro \& D. Sigogneau-Russell, eds.]. Mém. Mus. Nat. Hist. Nat. (C), 53: 241-254.

22. Wolsan M., Ruprecht A. L. \& Buchalczyk T., 1985: Variation and asymmetry in the dentition of the pine and stone martens (Martes martes and $M$. foina) from Poland. Acta theriol., 30: 79-114.

Received, August 20, 1987. Accepted, September 10, 1989. 

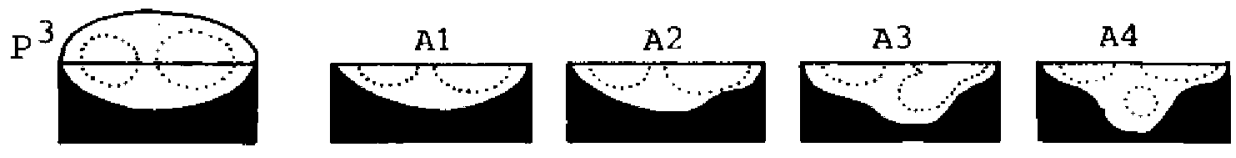

\section{MARTES MARTES}

$$
\begin{aligned}
& \text { A1 } \\
& \text { A2 } \\
& \text { A3 } \\
& \text { A4 }
\end{aligned}
$$

Austria $\mathrm{n}=60 \mathrm{~N}=118$

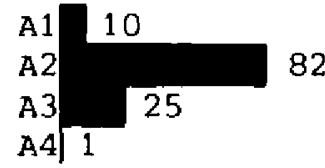

$$
\begin{aligned}
& \mathrm{S} \text { lovakia } \\
& \mathrm{n}=43 \quad \mathrm{~N}=86
\end{aligned}
$$

A1 2

$$
\text { A2 }
$$$$
\text { A3 }
$$

A4

Central

European USSR

$\mathrm{n}=46 \quad \mathrm{~N}=90$

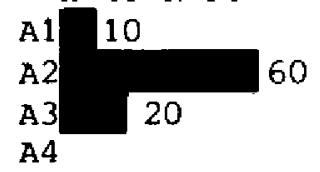

A4

$$
\begin{array}{ll}
\text { Ural Mts region } \\
n=10
\end{array}
$$

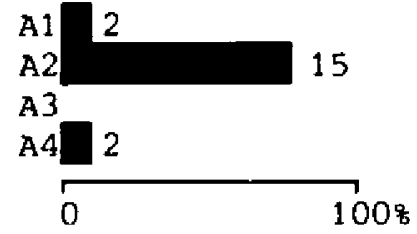

Bohemia

$\mathrm{n}=122 \mathrm{~N}=240$

6

25

6

Poland

$\mathrm{n}=224 \mathrm{~N}=438$

22

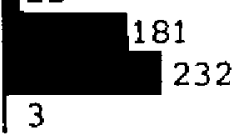

Ukraine

$n=24 \quad \mathrm{~N}=48$

8

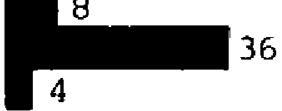

Total

$\mathrm{n}=810 \quad \mathrm{~N}=1581$

87

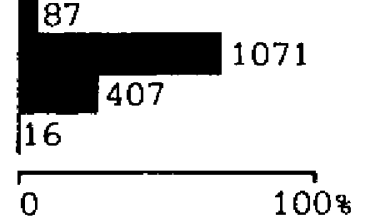

France

$\mathrm{n}=25 \mathrm{~N}=50$

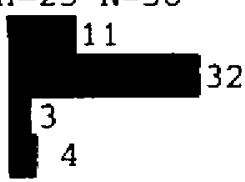

Moravia

$\mathrm{n}=42 \quad \mathrm{~N}=80$

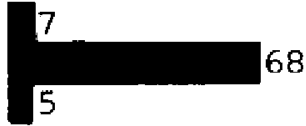

North European USSR

$\mathrm{n}=125 \mathrm{~N}=240$

9

48

Caucasus Mts region $\mathrm{n}=89 \mathrm{~N}=172$

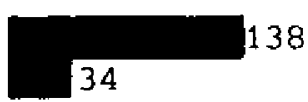

Total (ASYMMETRY) $\mathrm{n}=1 / 2 \mathrm{~N}=771$

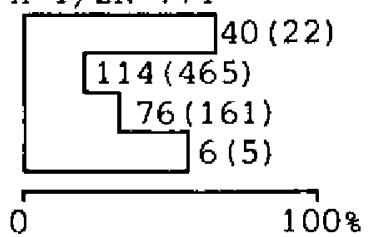

Fig. 1. Diagrams, frequency distributions, and right-left asymmetry of the mophotypes of group A. For solid histograms, the percentage frequency (horizontal scale) is plotted against the corresponding morphotype (vertical scale). For open histograms, the percentage of unilateral occurrences in the sum of unilateral and bilateral occurrences (horizontal scale) is plotted against the corresponding morphotype (vertical scale). The numbers to the right of the horizontal solid bars show the absolute frequencies of the corresponding morphotypes. The numbers to the right of the horizontal open bars indicate the absolute frequencies of the unilateral and, in parentheses, bilateral occurrences of the corresponding morphotypes. $\mathrm{N}$ and $\mathrm{n}$ are the numbers of scored teeth and skulls, respectively. Continued on pp. 557-558. 


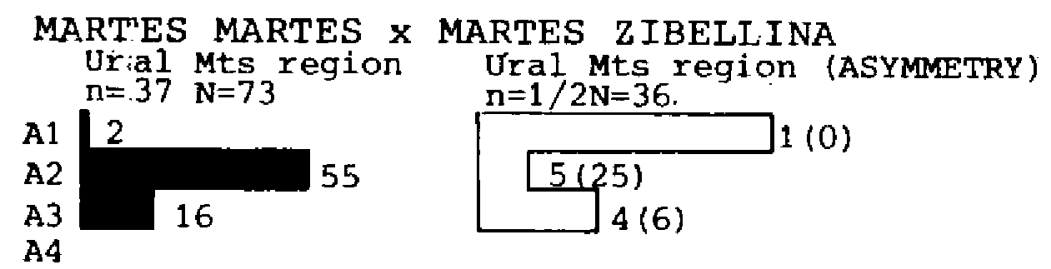

\section{MART"ES ZIBELIINA \\ Ural Mts region}

$\mathrm{n}=142 \mathrm{~N}=274$

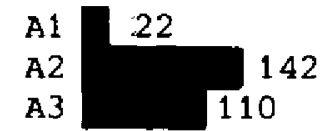

A4

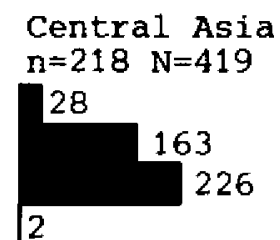

Kamchatka $\mathrm{n}=300 \quad \mathrm{~N}=574$

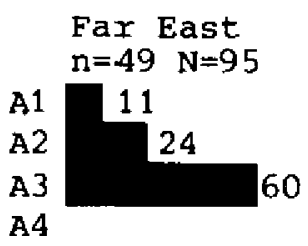

Total

$\mathrm{n}=709 \mathrm{~N}=1362$

132
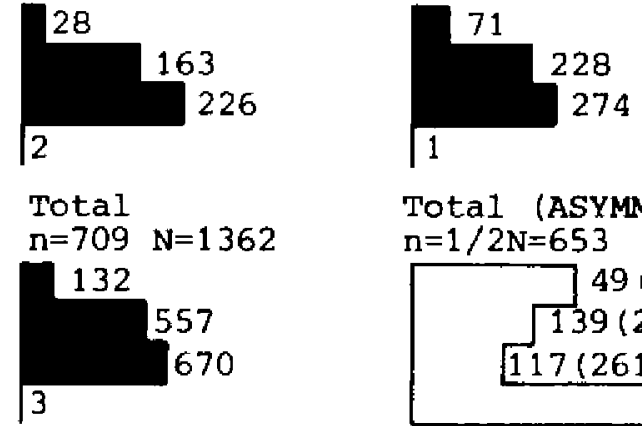

Tota1 (ASYMMETRY) $\mathrm{n}=1 / 2 \mathrm{~N}=653$

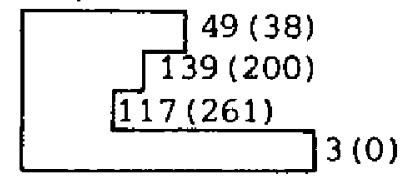
MARTES MELAMPUS
Japan
$n=1 \quad N=2$

Japan (ASYMMETRY)

$\mathrm{n}=1 / 2 \mathrm{~N}=1$

A1

A2

A3

A4

$0(1)$

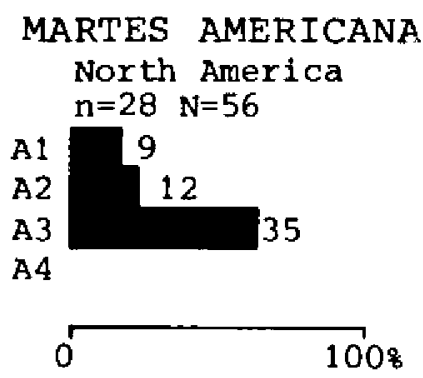

North America (ASYMMETRY) $n=1 / 2 \mathrm{~N}=28$

$\square 1(4)$

$0(6)$

]1(17)

1008
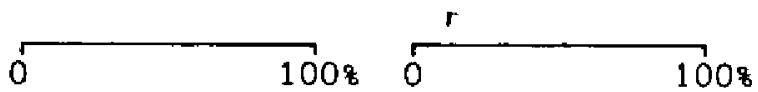

Fig. 1. Continued. 


\section{MARTES FOINA}

A 1

A2

A3

A4

Austria

$$
n=47 \quad N=92
$$

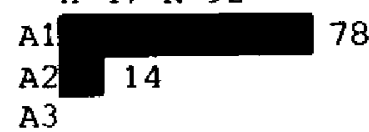

A3

A4
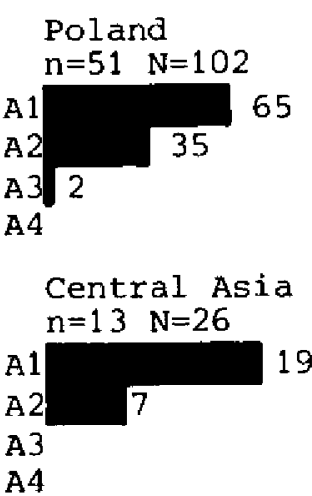

MARTES FLAVIGULA

$$
\text { Fax East }
$$$$
\mathrm{n}=48 \quad \mathrm{~N}=92
$$

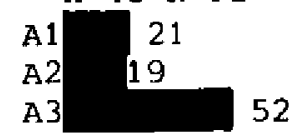

A4

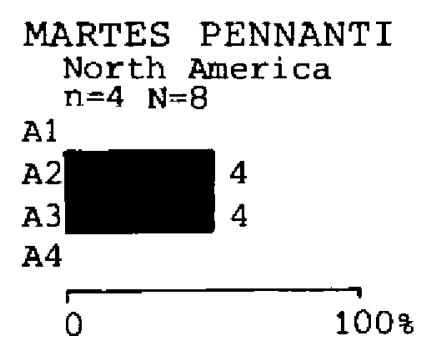

France

$\mathrm{n}=63 \mathrm{~N}=115$

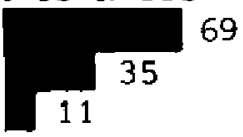

Moravia

$n=109 \quad N=210$

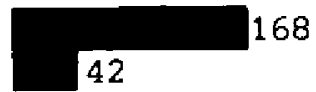

$\mathrm{n}=135 \mathrm{~N}=262$

198

$61 \quad 42$

3

Ukraine

$\mathrm{n}=48 \quad \mathrm{~N}=94$

Caucasus Mts region $n=79 \quad \mathrm{~N}=151$

85

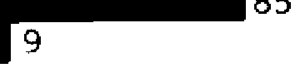

Total

$n=545 \quad N=1052$

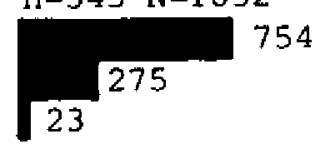

Total (ASYMMETRY)

$\mathrm{n}=1 / 2 \mathrm{~N}=507$

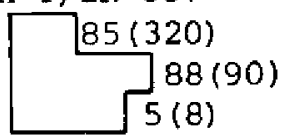

North America (ASYMMETRY) $\mathrm{n}=1 / 2 \mathrm{~N}=4$

$0(2)$

$0(2)$
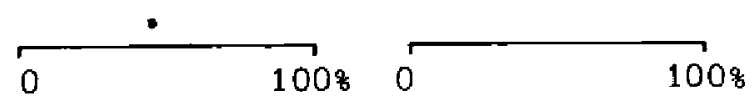

Fig. 1. Concluded. 


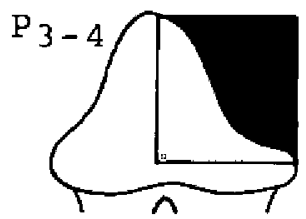

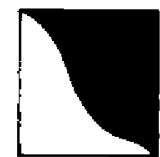

B 1

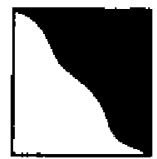

B2

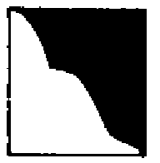

B3

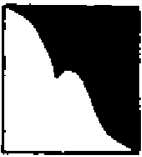

B4

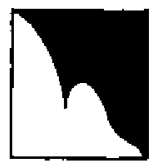

B5

\section{MARTES MARTES $\left(P_{3}\right)$}

B1

B2

B3

B4

B5
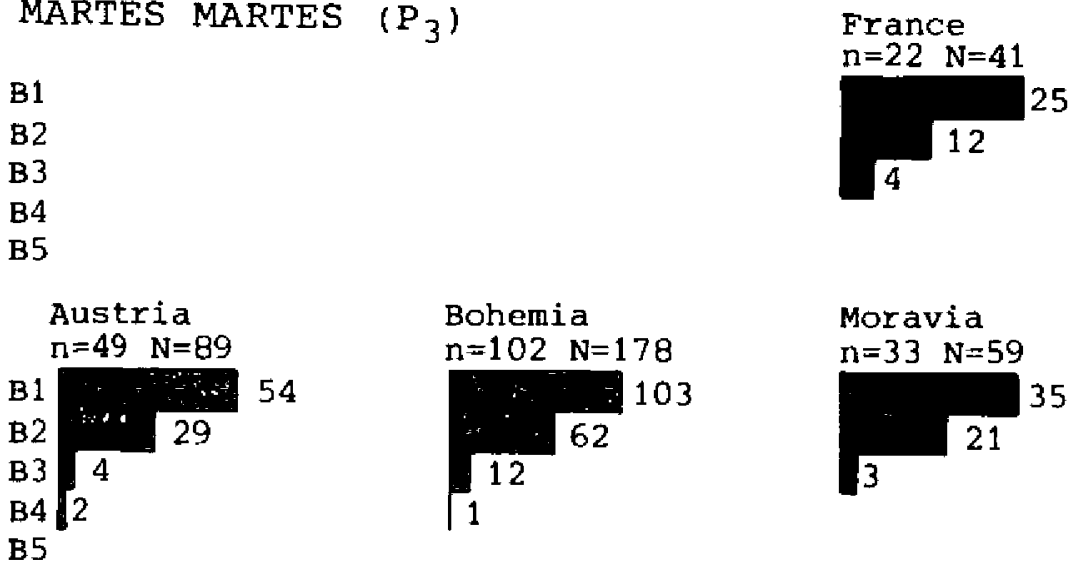

Slovakia

$\mathrm{n}=34 \mathrm{~N}=62$

B1 $\because \because 42$

$\mathrm{B} 2$

B3

B4

B5

Central

European USSR

$n=40 \quad N=79$

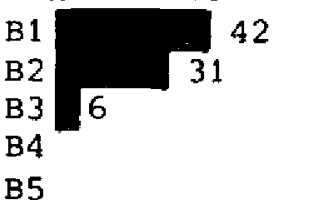

B5

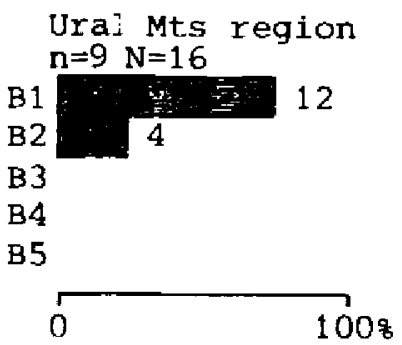

\section{Poland}

$\mathrm{n}=155 \mathrm{~N}=293$
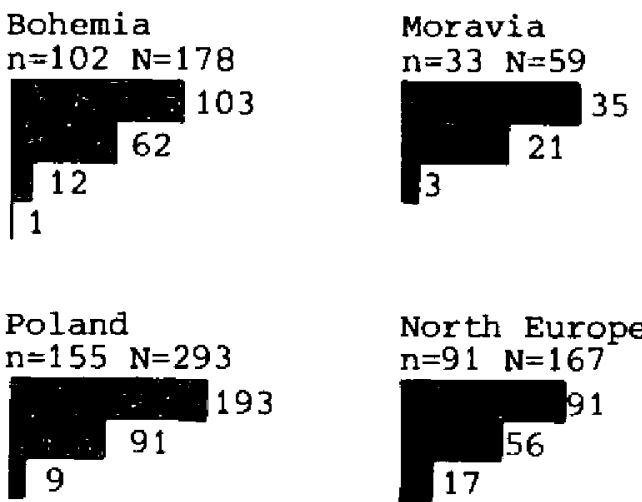

North European USSR $\mathrm{n}=91 \mathrm{~N}=167$
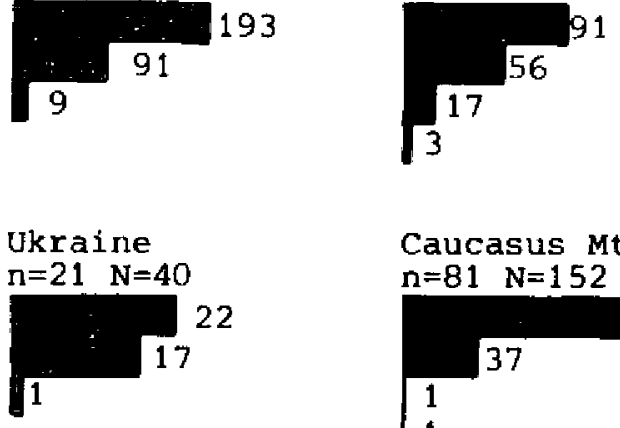

Caucasus Mts region $n=81 \quad N=152$
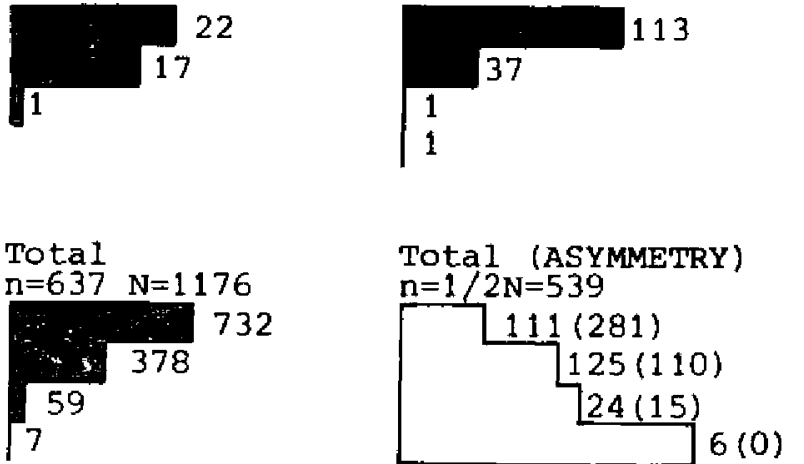

Total (ASYMMETRY) $\mathrm{n}=1 / 2 \mathrm{~N}=539$

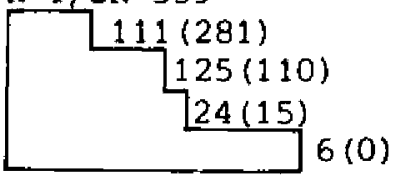

Fig. 2. Dagrams, frequency distributions, and right-left asymmetry of the morphotypes of group B. For explanation see Fig. 1. Continued on pp. 560-564. 


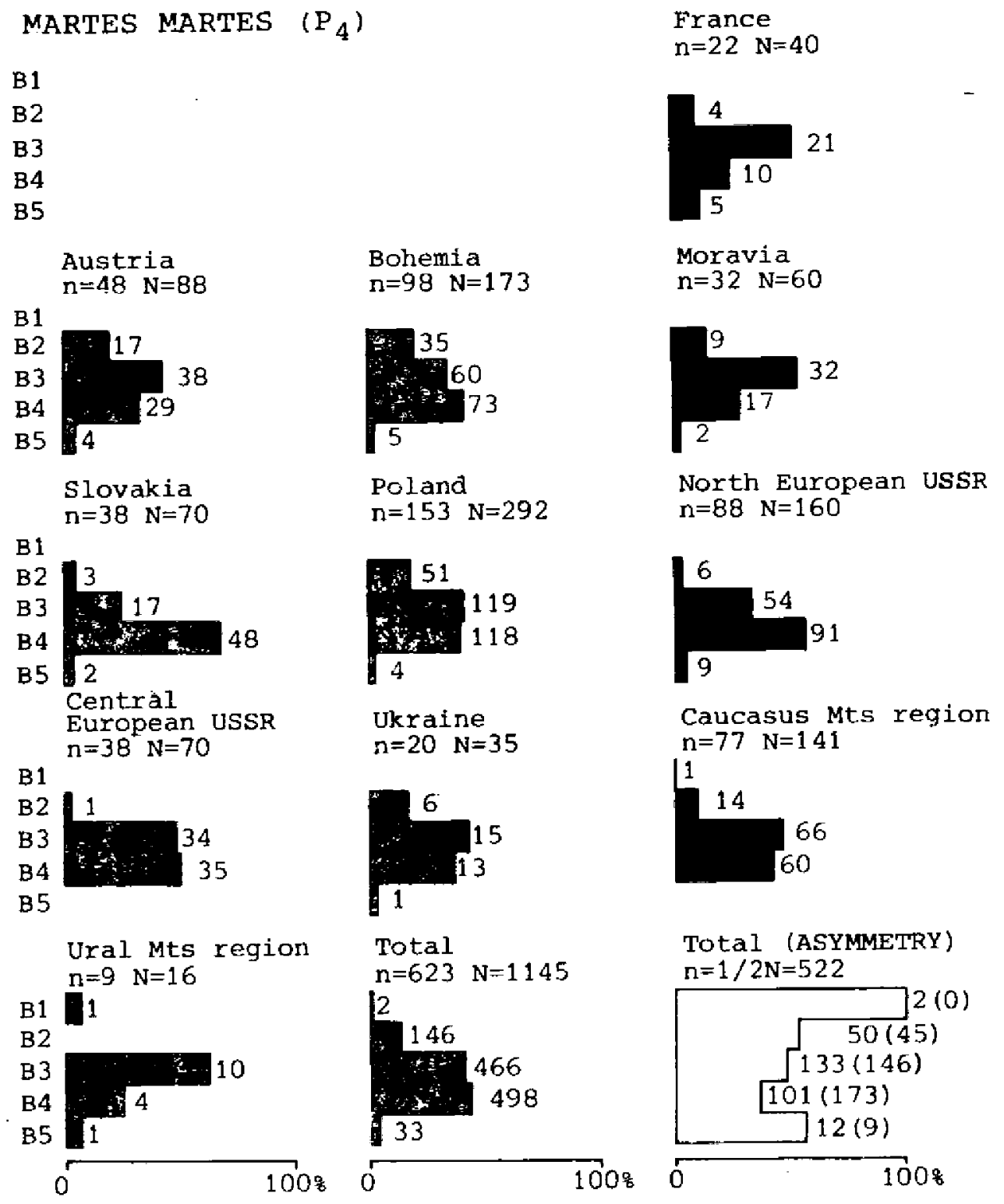

Fig. 2. Continued. 


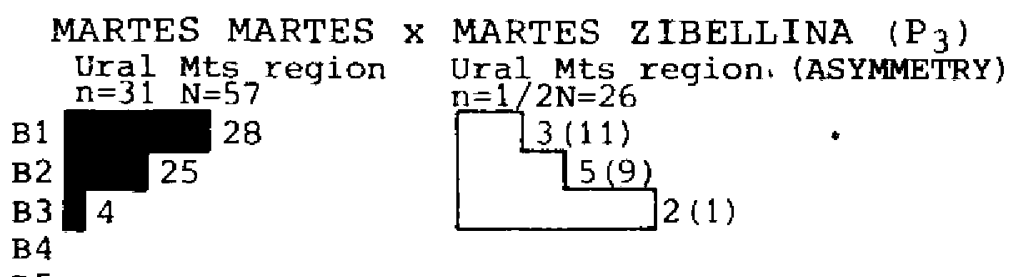

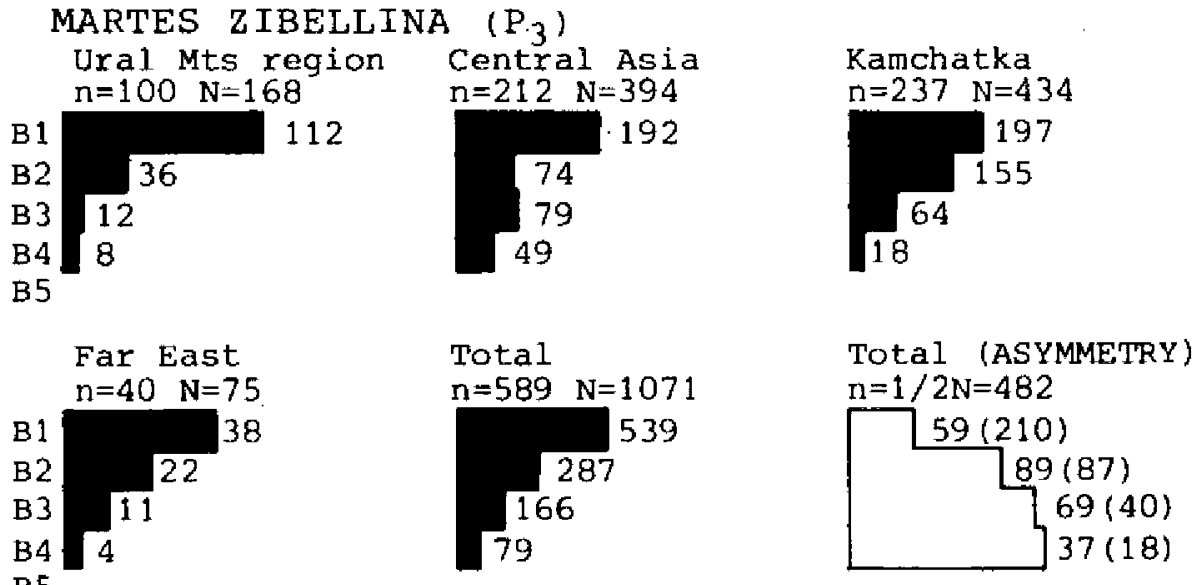

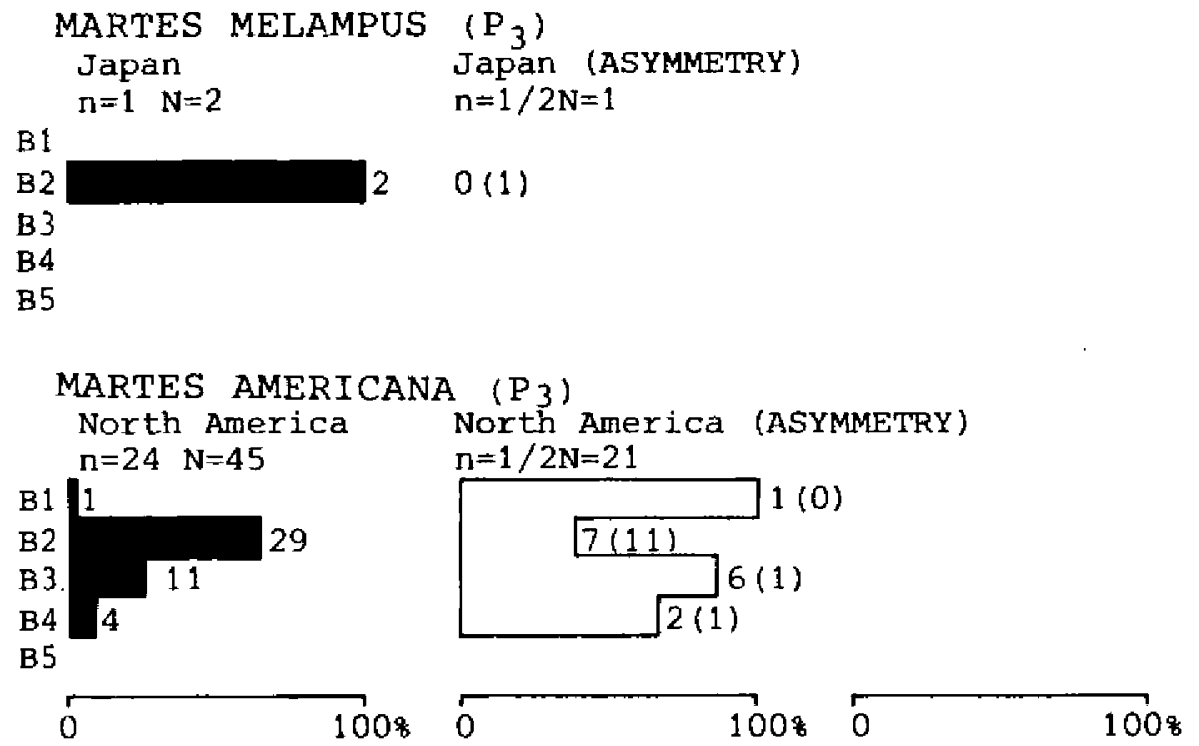

Fig, 2. Continued. 


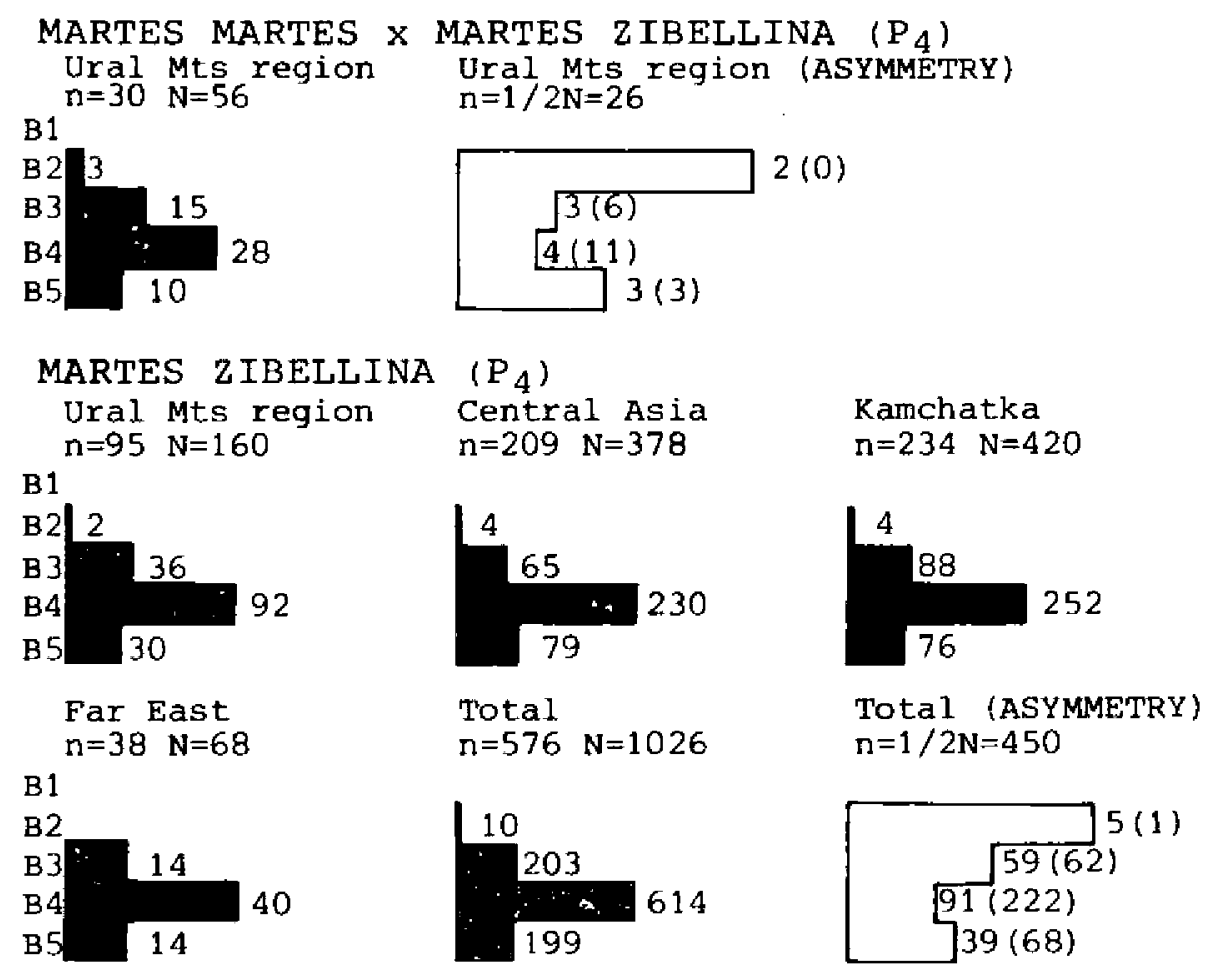

\section{MARTES MELAMPUS $\left(\mathrm{P}_{4}\right)$

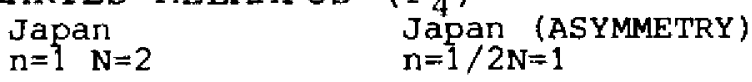

B2

B3

B4

B $5-2 \quad 0(1)$
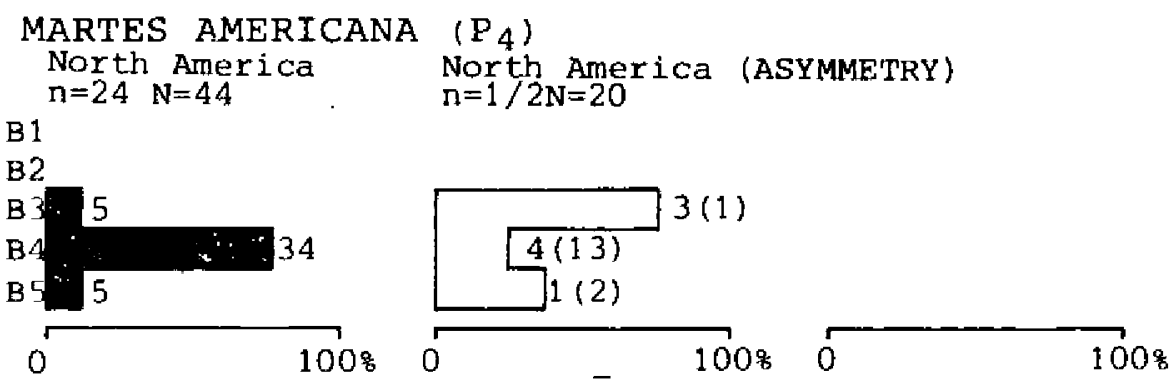

Fig. 2. Continued. 


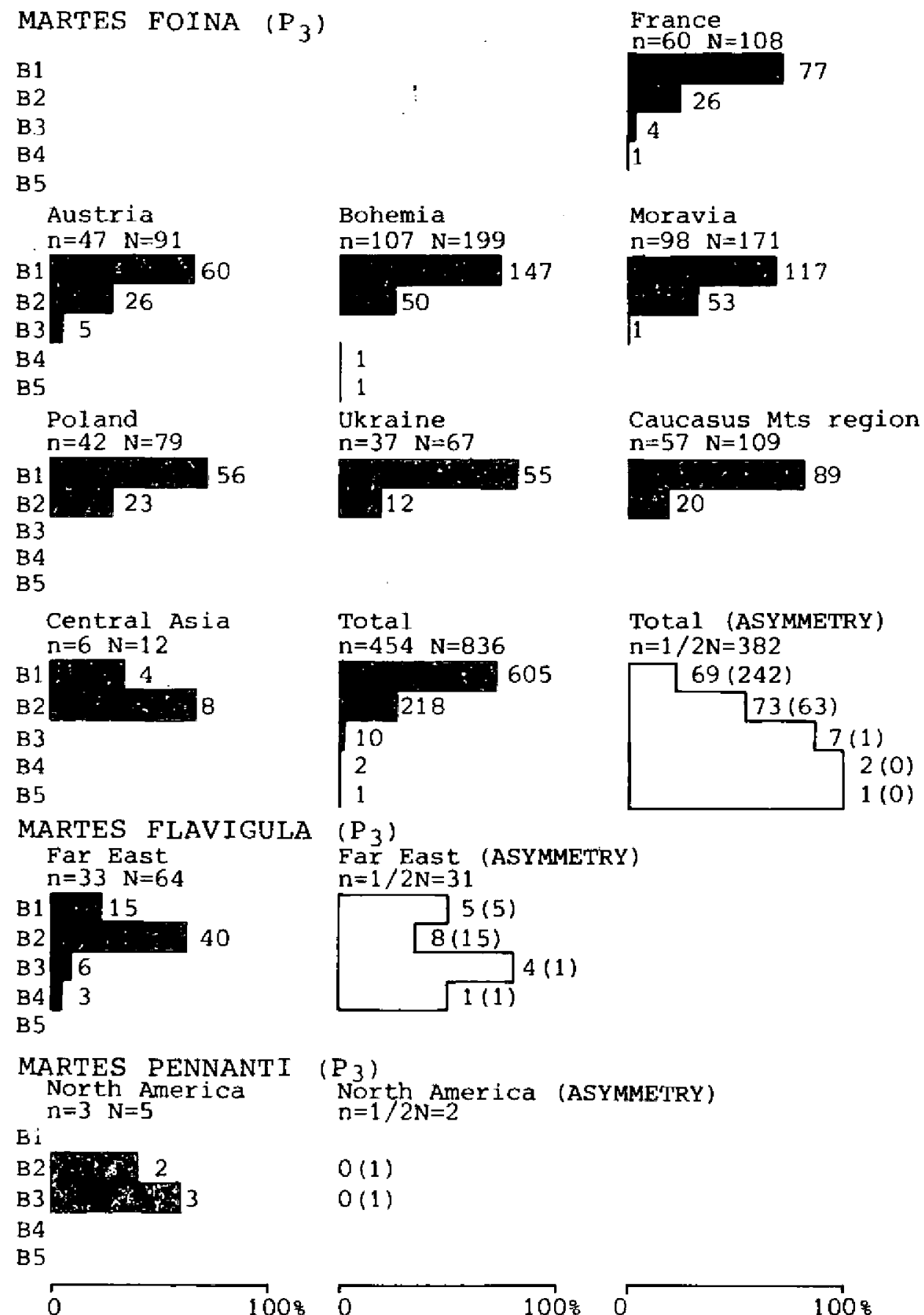

Fig. 2. Continued 


\section{B1 \\ B2 \\ B3 \\ B5}

MARTES FOINA $\left(\mathrm{P}_{4}\right)$

B4
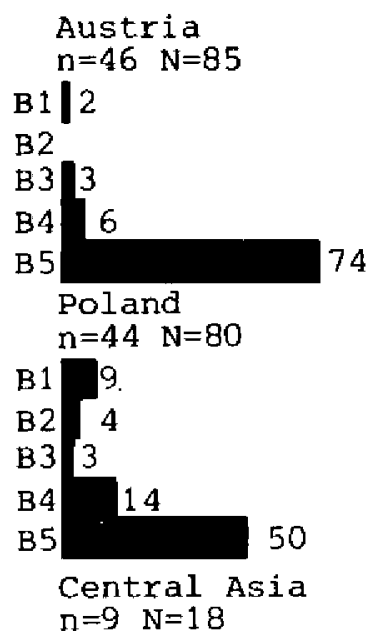

B1

B2

B3

B4

B5

MARTES FLAVIGULA

Far East

$n=32 \quad N=63$

B1

B2

B $3: 8$

$\mathrm{B} 4$
$\mathrm{~B} 5$$\quad 25$

MARTES PENNANTI

North America

$n=3 \quad N=6$

B1

$B 2$

B3

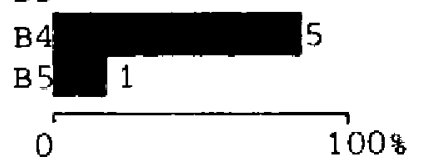

Bohemia

$\mathrm{n}=108 \mathrm{~N}=195$

(11

15

15

Ukraine

$\mathrm{n}=36 \quad \mathrm{~N}=59$

10

4

8
10

27

Total

$\mathrm{n}=435 \quad \mathrm{~N}=777$

48

23

37

108

$\left(\mathrm{P}_{4}\right)$

Far East (ASYMMETRY)

$n=1 / 2 N=31$

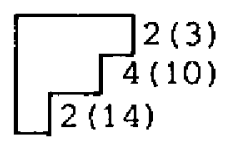

$\left(\mathrm{P}_{4}\right)$

North America (ASYMMETRY)

$\mathrm{n}=1 / 2 \mathrm{~N}=3$

\section{1}

France

$\mathrm{n}=44 \mathrm{~N}=80$

6

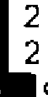

9

Moravia

$\Pi=92 \quad N=159$

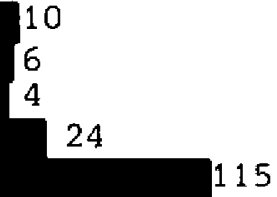

Caucasus Mts region $\mathrm{n}=56 \mathrm{~N}=101$

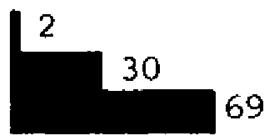

Total (ASYMMETRY) $\mathrm{n}=1 / 2 \mathrm{~N}=343$

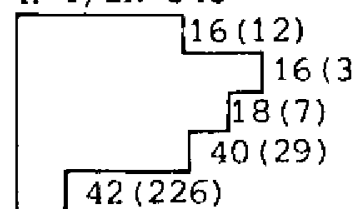

61

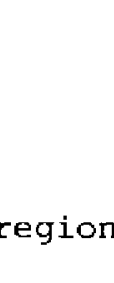



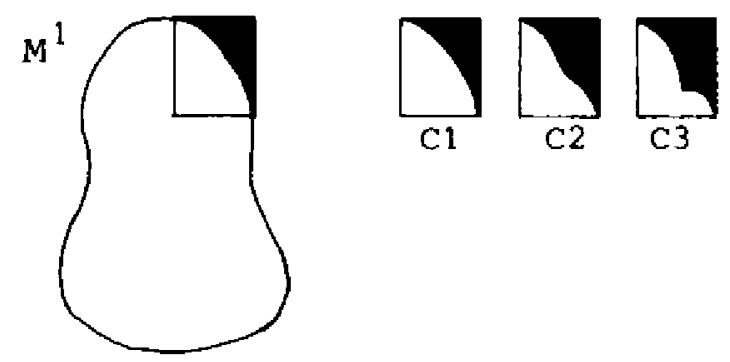

\section{MARTES MARTES}
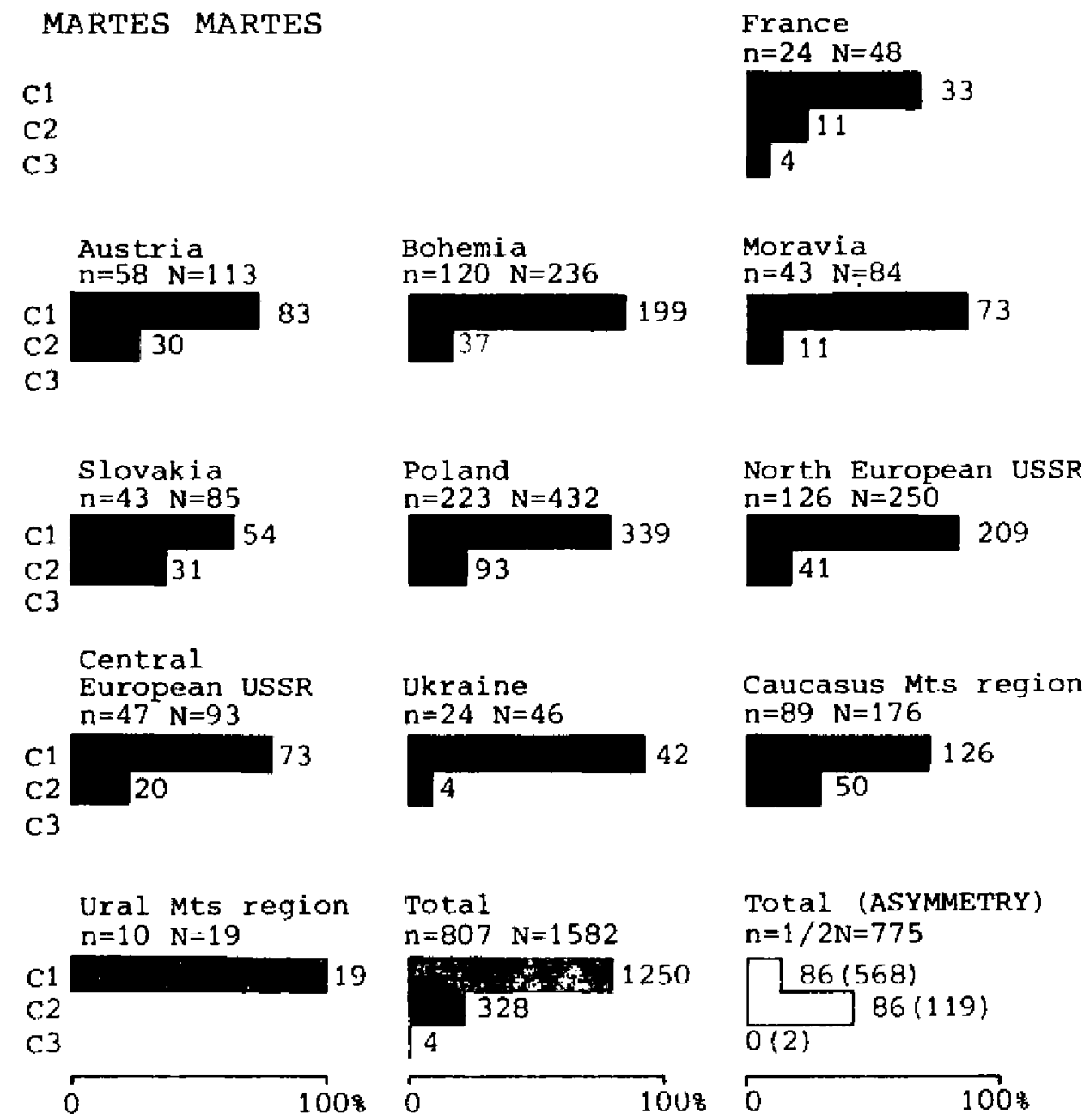

Fig. 3. Diagtams, frequency distributions, and right-left asymmetry of the morphotypes of group C. For explanation see Fig. 1. Continued on pp. 566-567. 

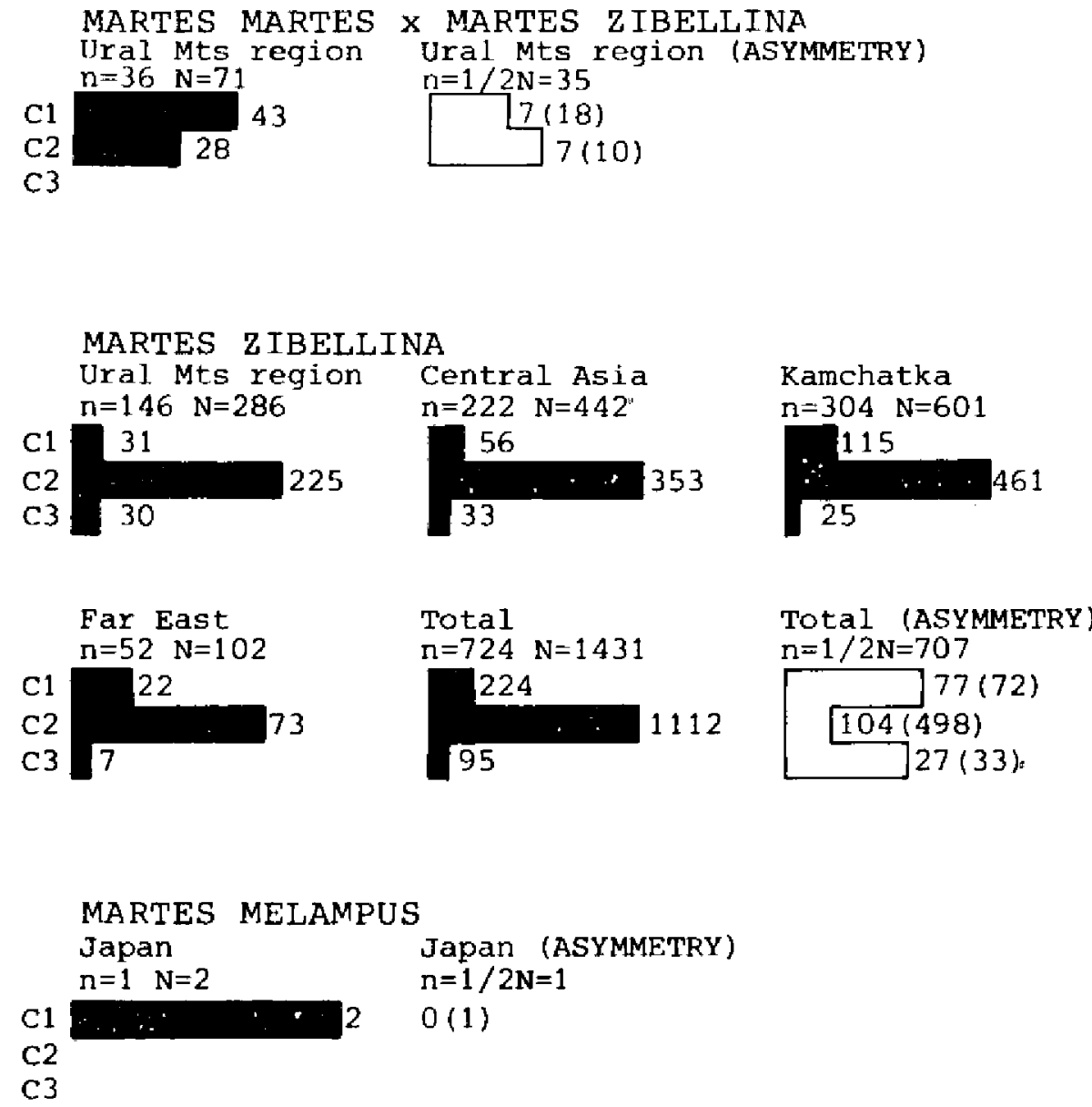

$\mathrm{C} 2$

c3

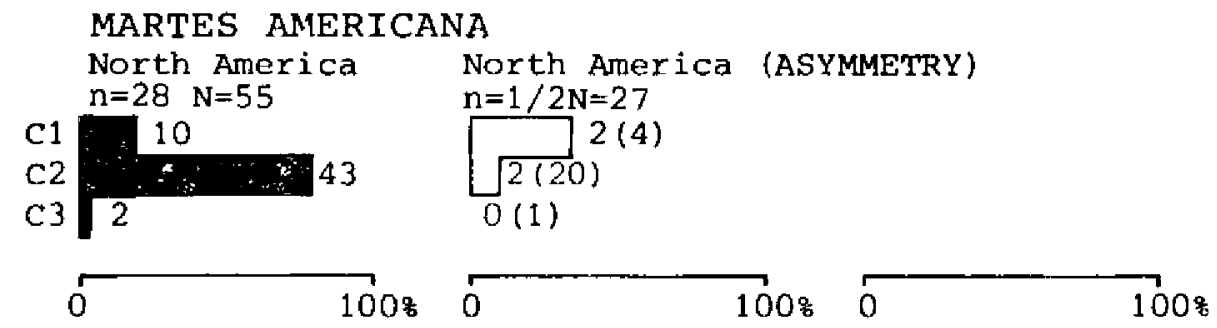

Fig. 3. Continued. 
MARTES FOINA

$c 1$

C2

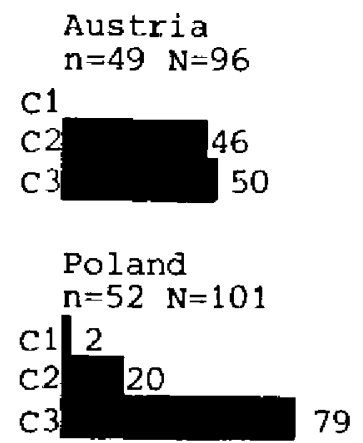

Central Asia $\mathrm{n}=13 \mathrm{~N}=26$

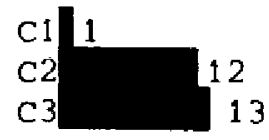

France

$\mathrm{n}=66 \quad \mathrm{~N}=128$

1

52

75

Moravia

Bohemi a

$n=133 \quad N=252$

1

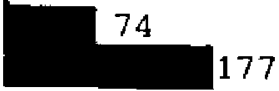

$n=115 \quad N=222$

1

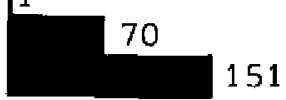

Ukraine

$\mathrm{n}=52 \mathrm{~N}=106$

2

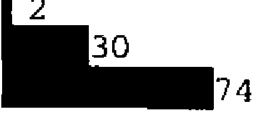

Caucasus Mts region $n=83 \quad N=164$

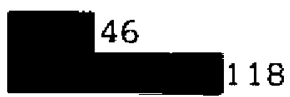

Total

$n=563 \quad \mathrm{~N}=1095$

8

373

714

Total (ASYMMETRY)

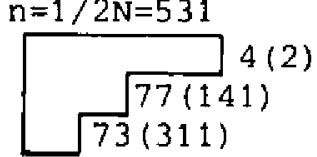

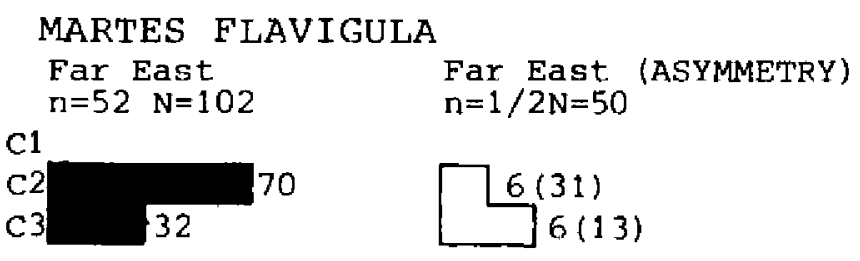

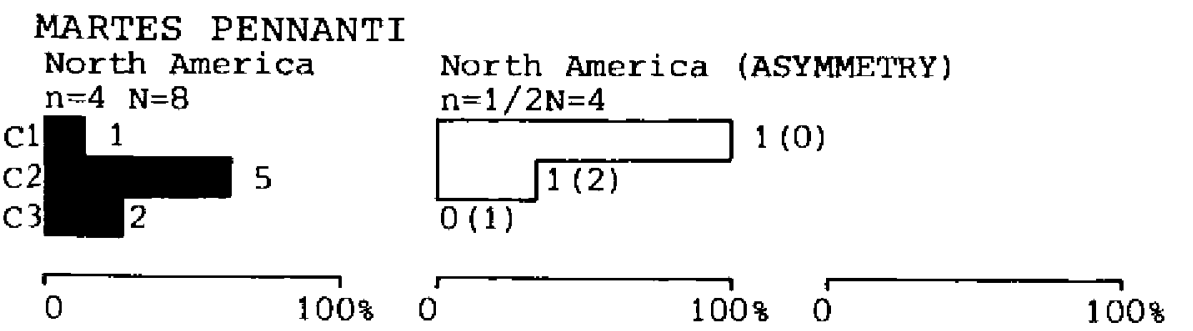

Fig. 3, Concluded. 

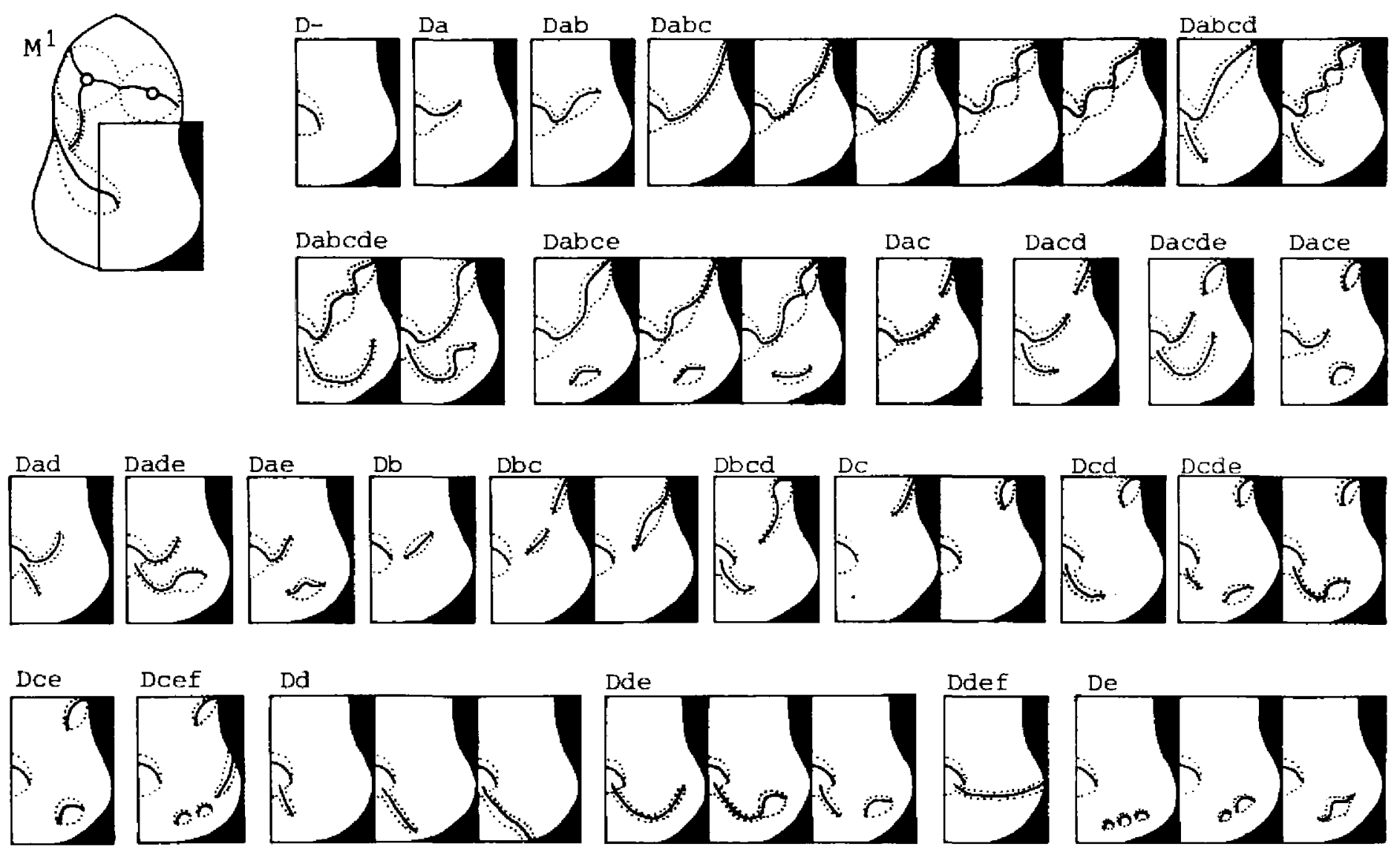

Fig. 4. Diagrams, frequency distributions, and right-left asymmetry of the morphotypes of group D. For explanation see Fig. 1 Continued on pp. 569--578. 

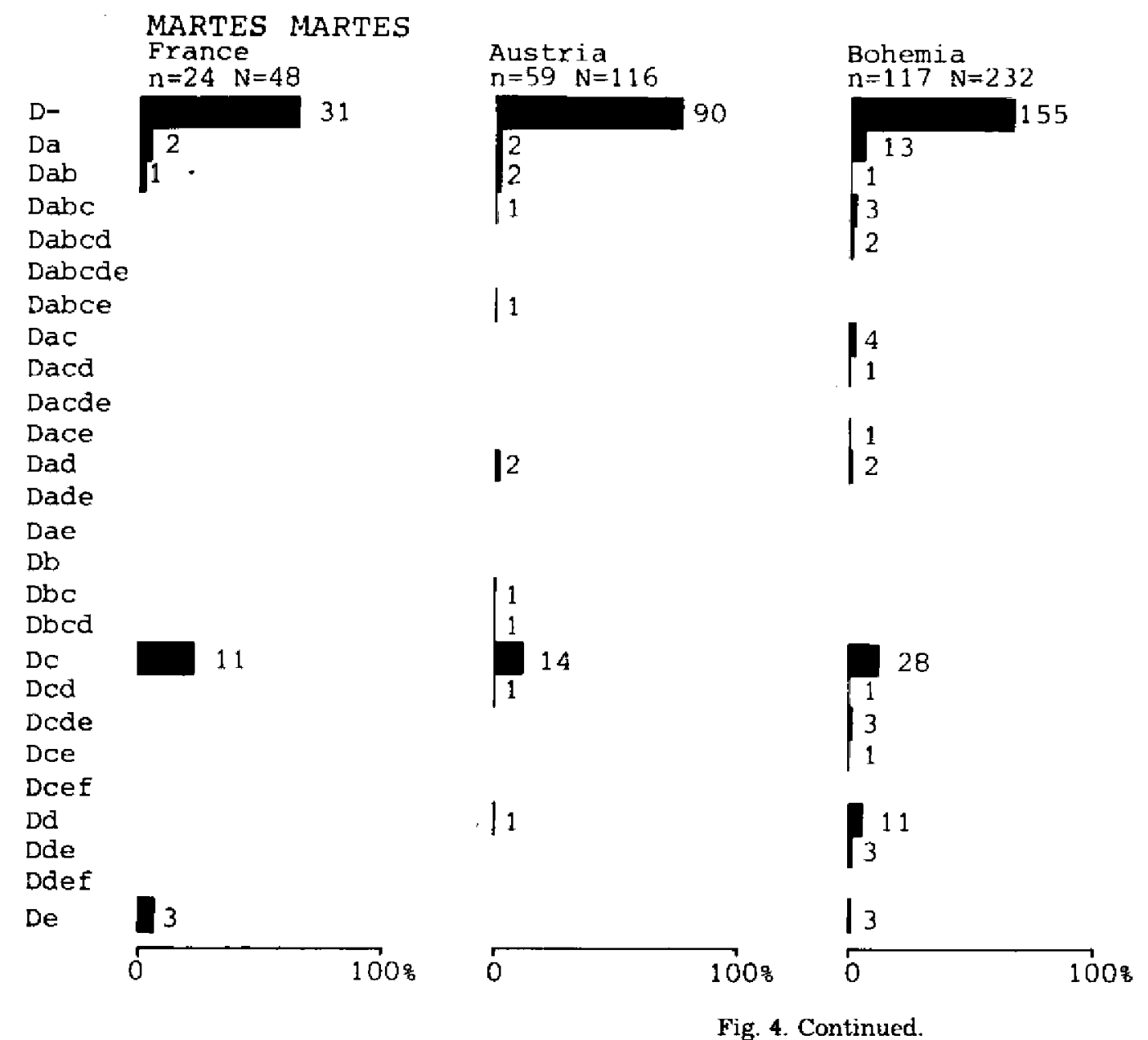

Moravia

$\mathrm{n}=42 \quad \mathrm{~N}=84$

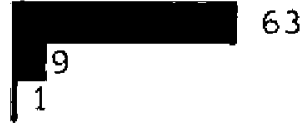

$l_{1}^{2}$

11

I 1

I 3

12

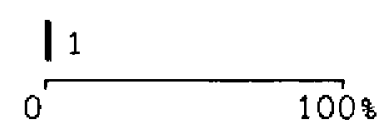




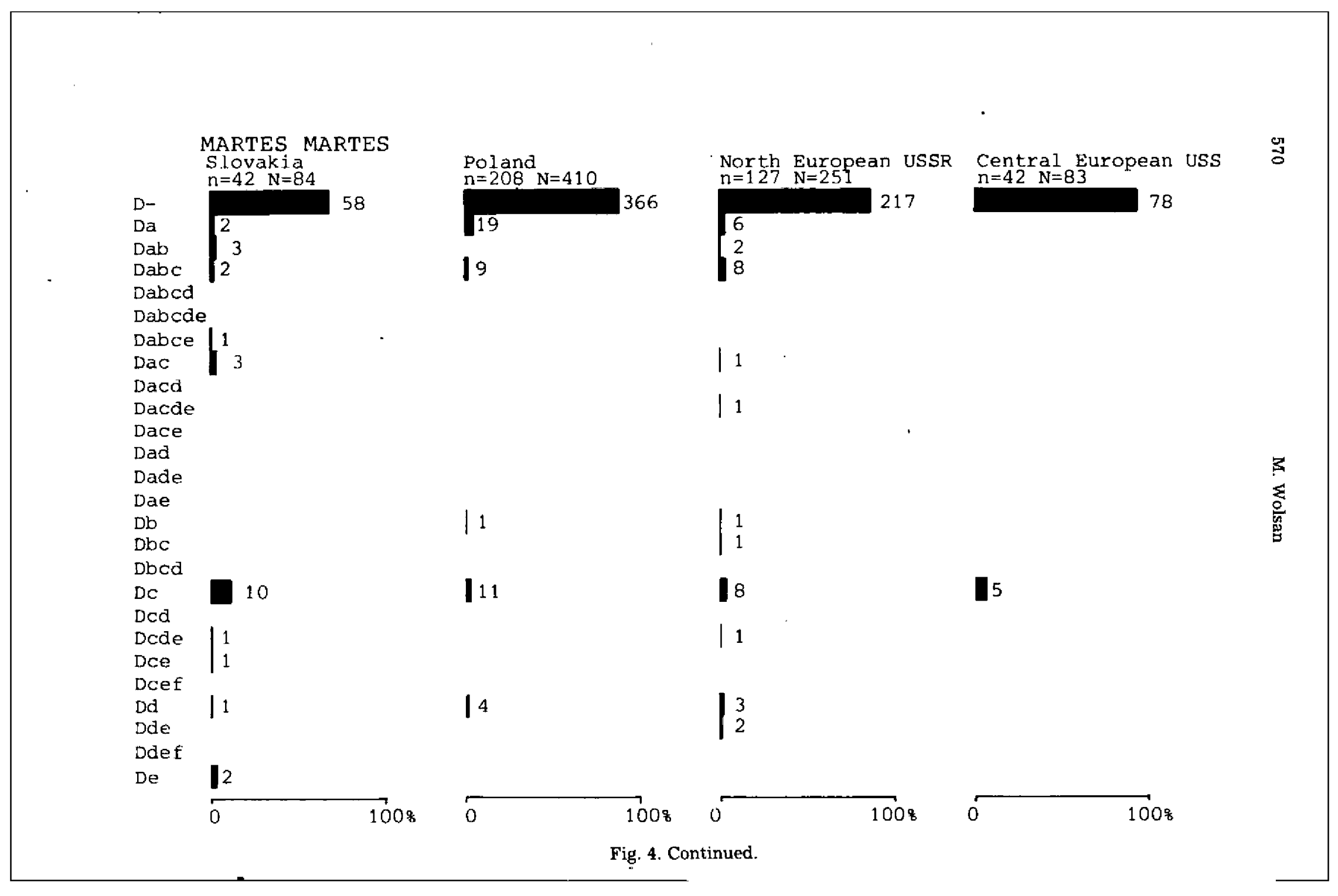




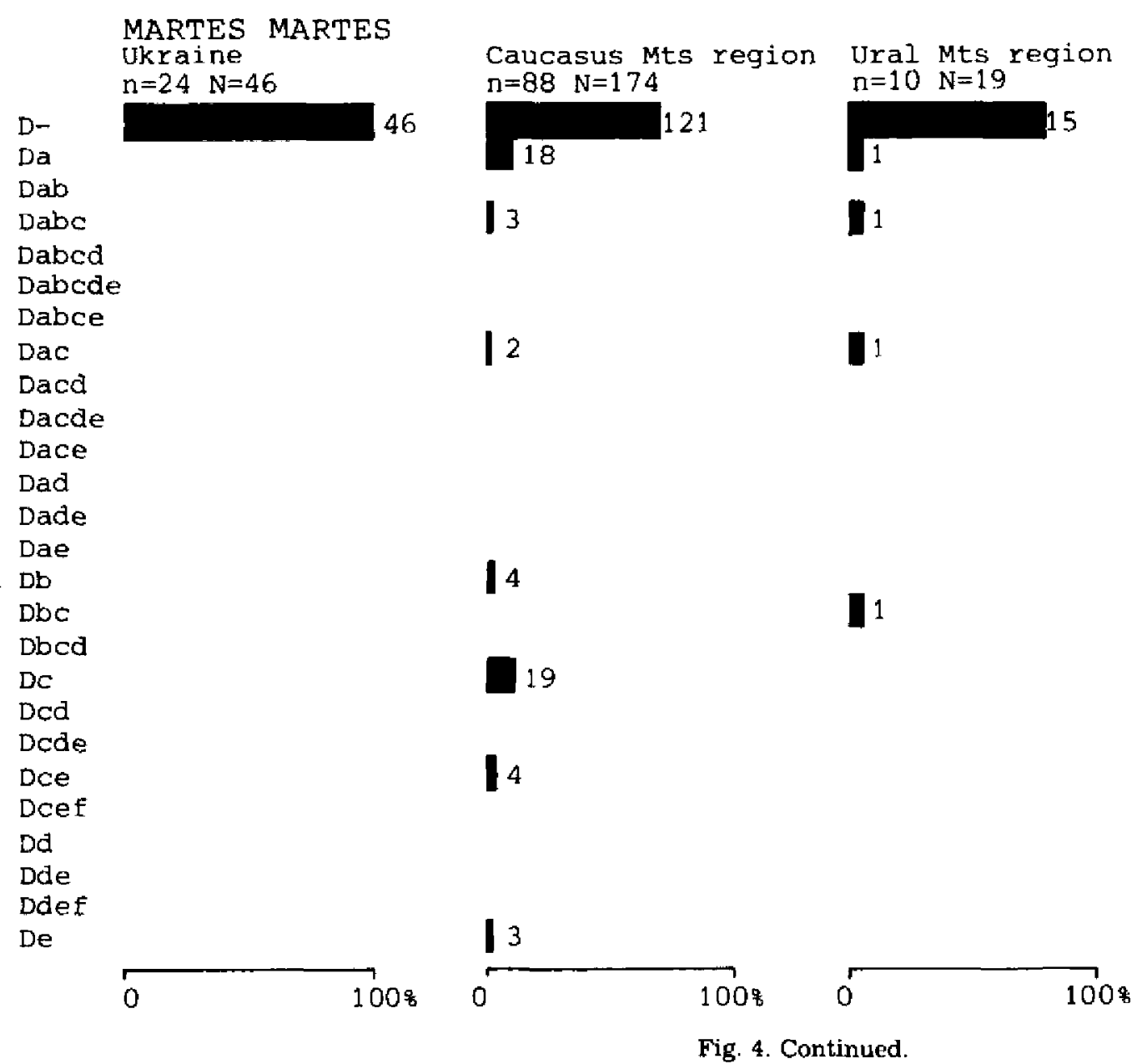

Tota

$\mathrm{n}=783 \mathrm{~N}=1547$

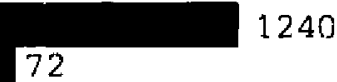

72

27

2

12

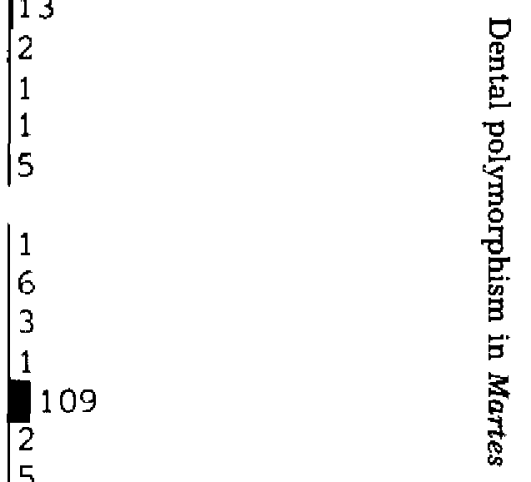

6

$\left.\right|_{5} ^{22}$

12

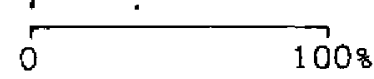




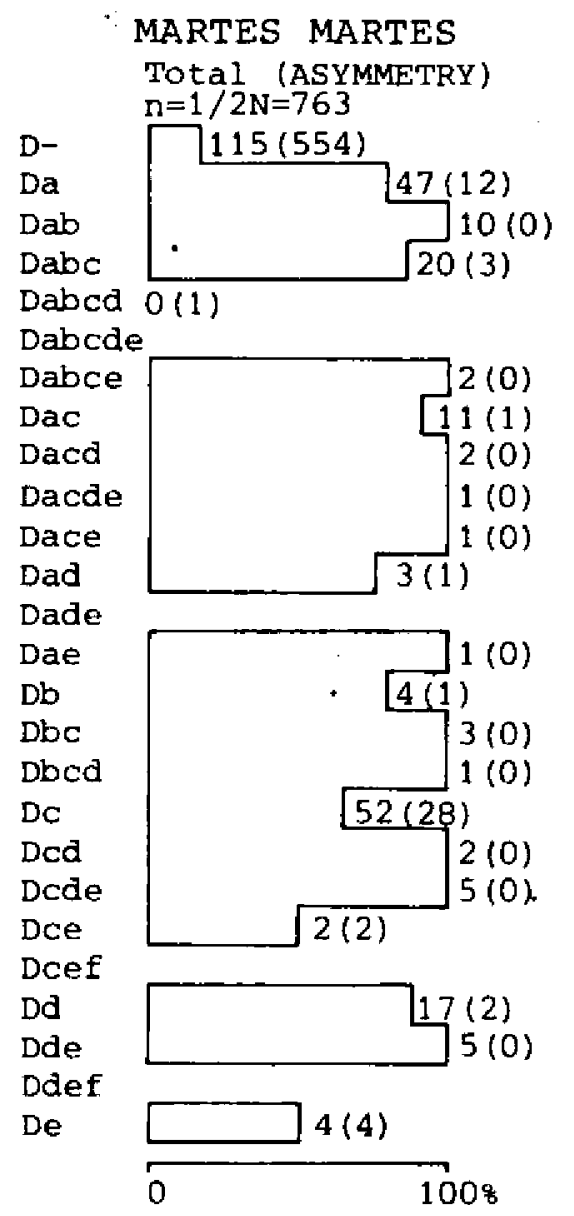

MARTES MARTES $\times$ MARTES ZIBELLINA

Ural Mts region Ural Mts region (ASYMMETRY)

$\mathrm{n}=34 \mathrm{~N}=67$

$4(26)$

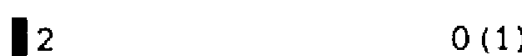

$0(1)$

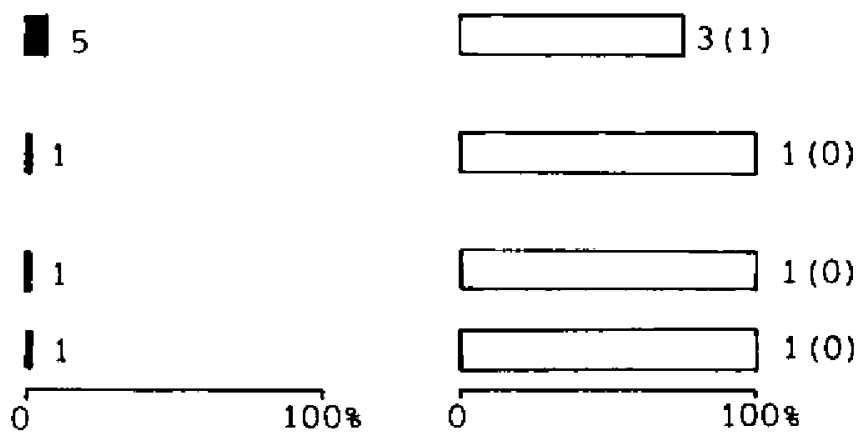

Fig. 4. Continued. 


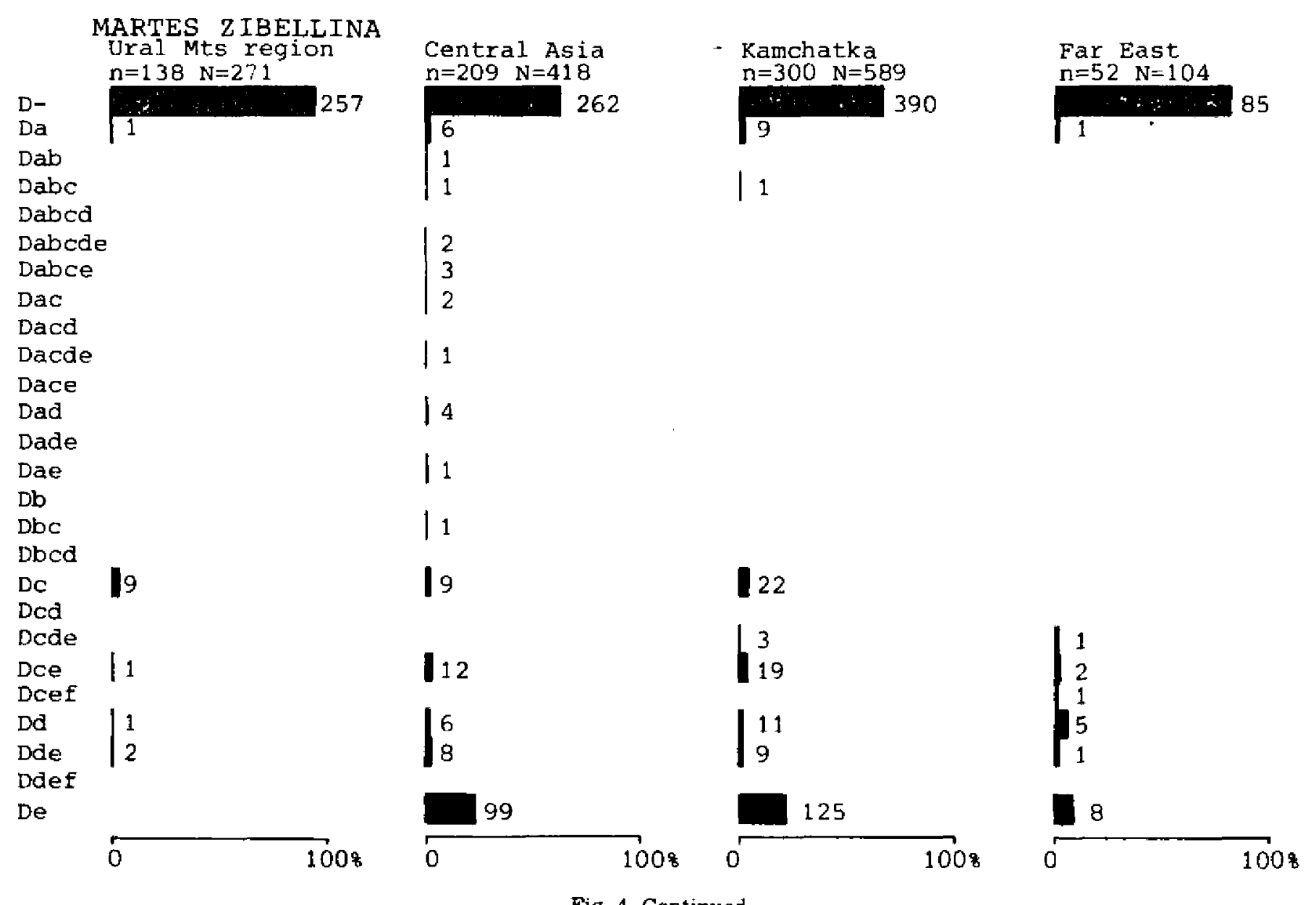




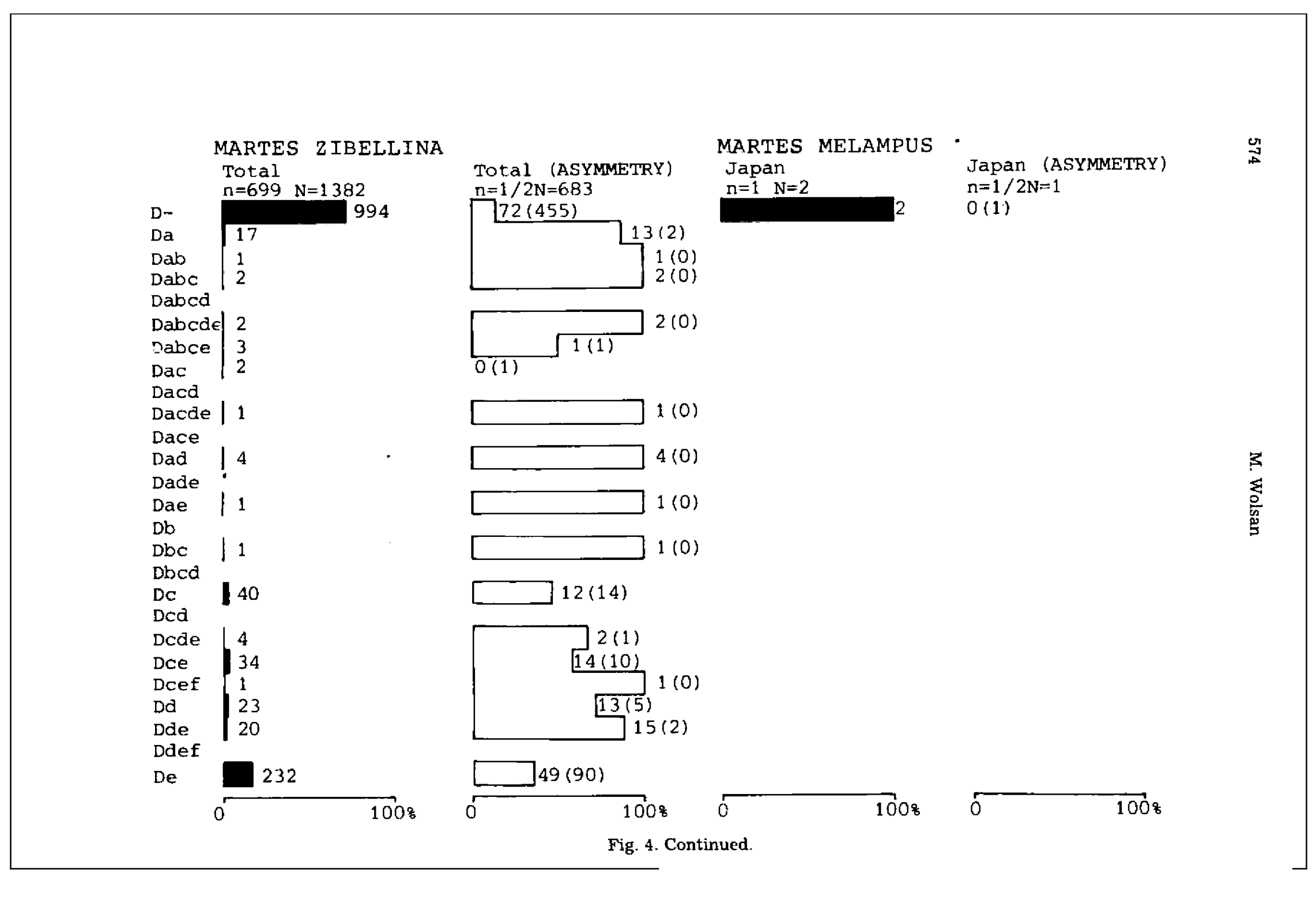




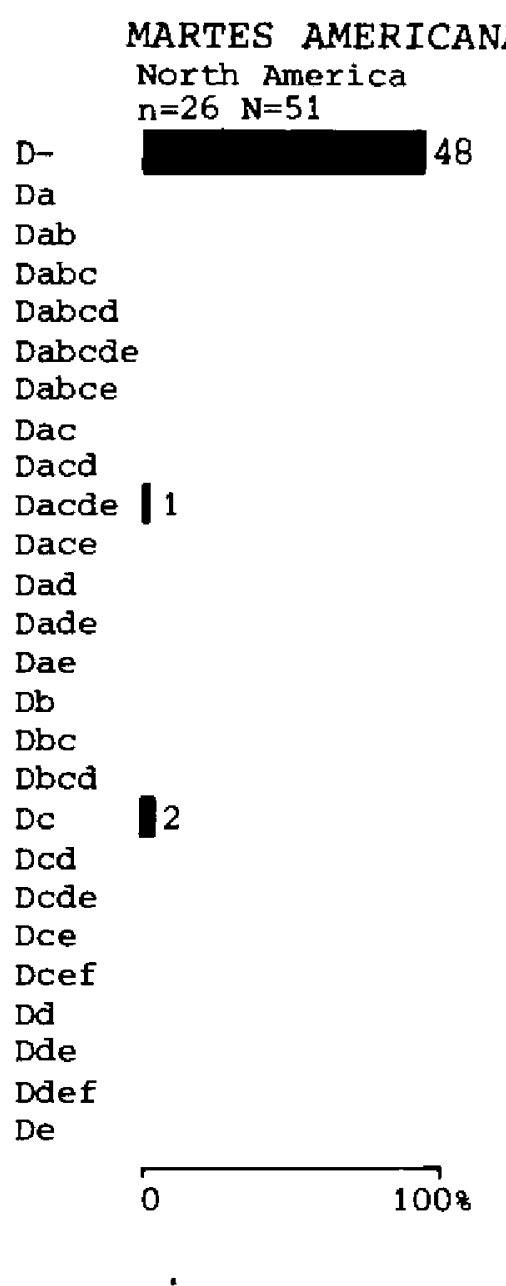

North

America (ASYMMETRY)

$\mathrm{n}=1 / 2 \mathrm{~N}=25$

$\square 2$ (23)

MARTES FOINA

France

$n=65 \quad N=127$

72
Austria

$\mathrm{n}=47 \mathrm{~N}=91$

Dabcd

Dabce

Dac

Dacd

$\mathrm{Dbca}$

DCd
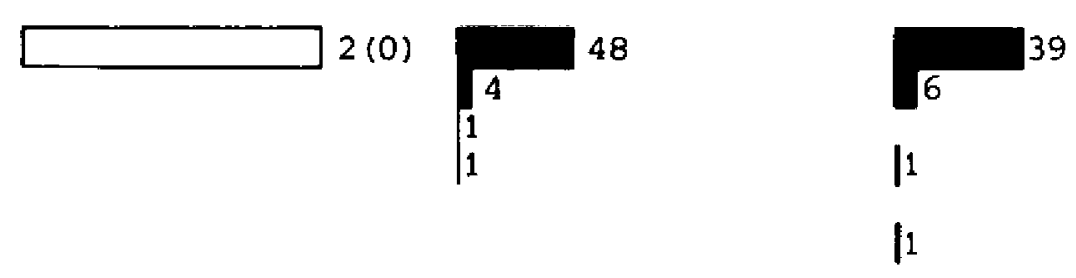

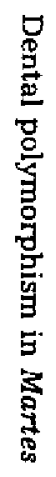

$\mid 1$
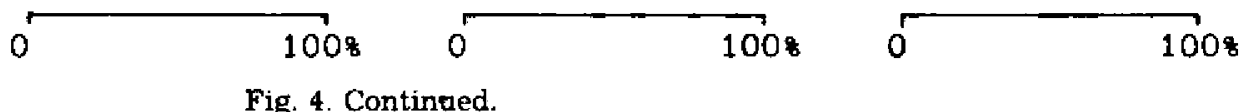

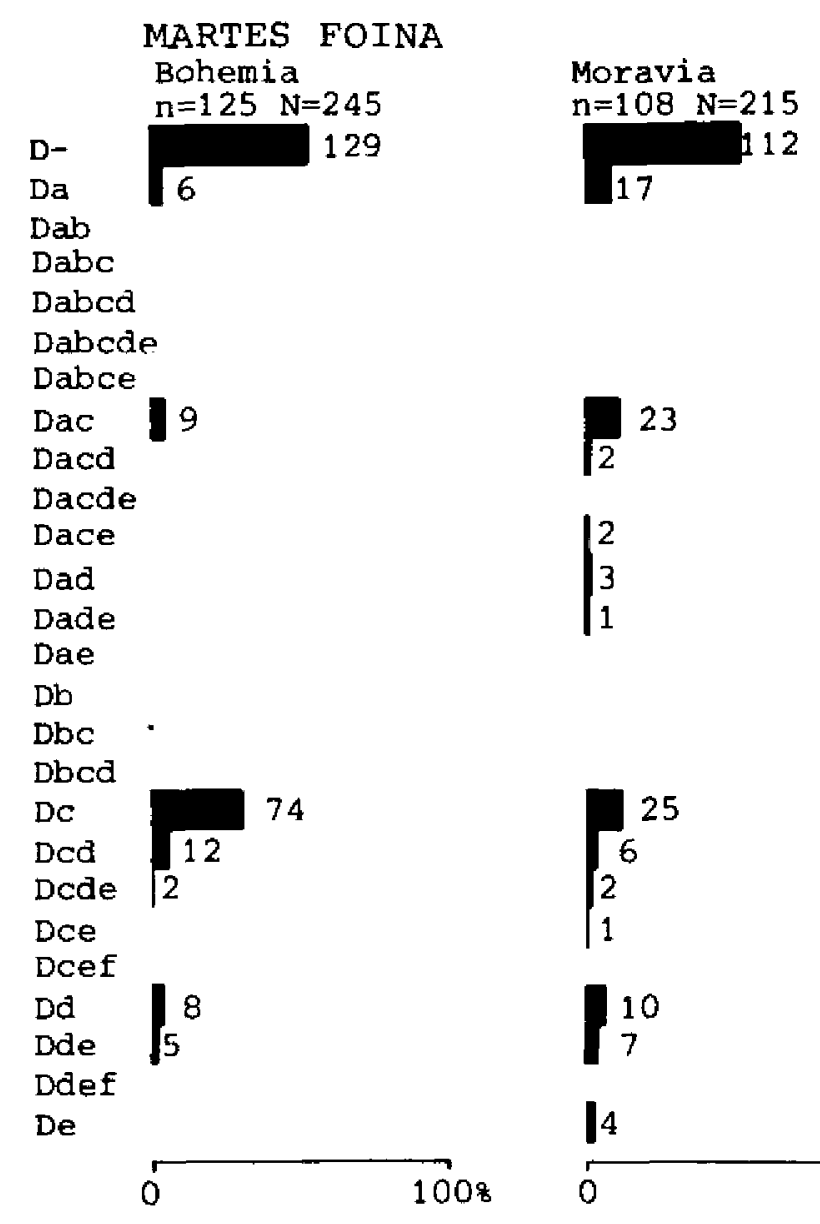

Poland
$\mathrm{n}=50 \quad \mathrm{~N}=99$

Ukraine

$\mathrm{n}=49 \quad \mathrm{~N}=98$

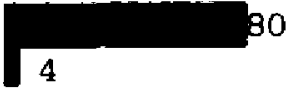

$\pi_{2}^{23}$

| 2

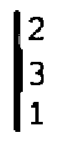

3
3
0
$\frac{2}{20}$
$\vdots$
0

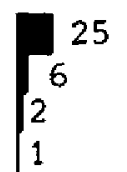

12

16

$1_{7}^{10}$

I 3

| 4

$\overline{100} 8$

0

1008

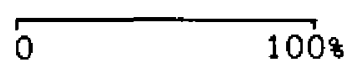

Fig. 4. Continued 
MARTES FOINA

Caucasus Mts region Central Asia

Total

$\mathrm{n}=82 \mathrm{~N}=160$

$\mathrm{n}=13 \mathrm{~N}=26$

$n=539 \quad \mathrm{~N}=1061$

$$
\text { D- }
$$

111

Da

27

Total (ASYMMETRY)

$\mathrm{n}=1 / 2 \mathrm{~N}=522$

Dab

Dabcd

Dabcde

Dabce

Dac

Dacd

Dacde

Dace

Dad

Dade

Dae

$\mathrm{Db}$

Dbc

Dboa

Dbca

DC

DCd

Dcde

Dce

Dcef

Dd

Dde

Ddef

De
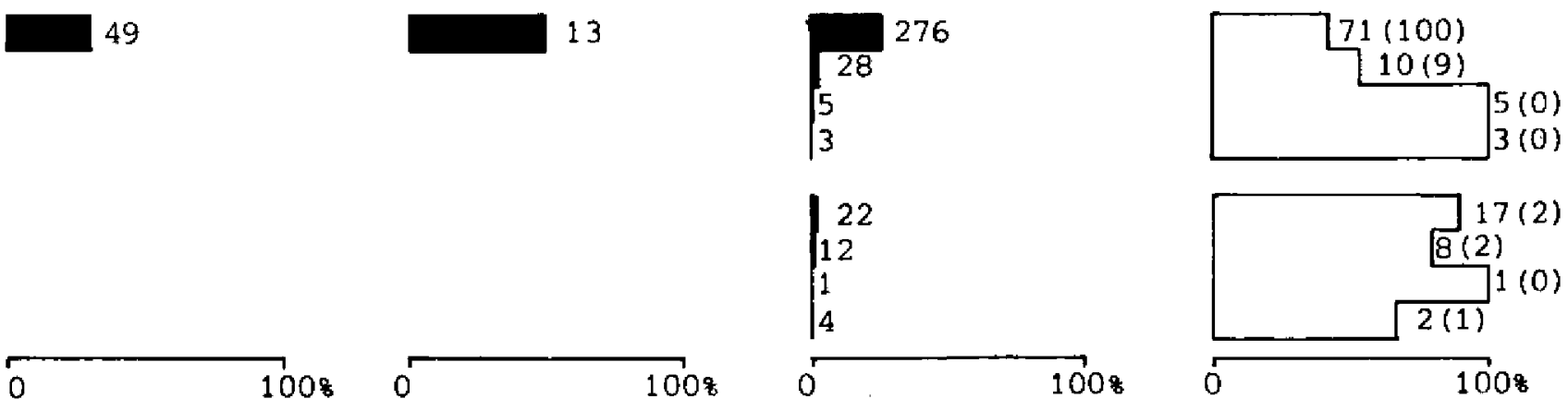

22

12
1
4

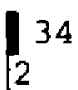

$\mid \begin{aligned} & 2 \\ & 3 \\ & 1\end{aligned}$

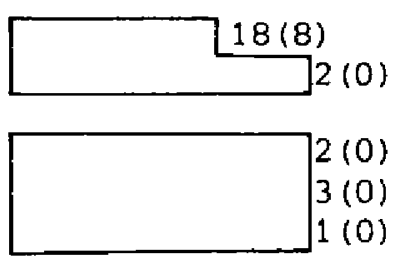

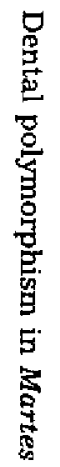

Fig. 4. Continued.

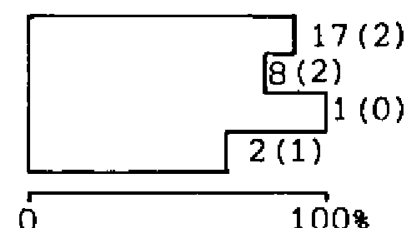




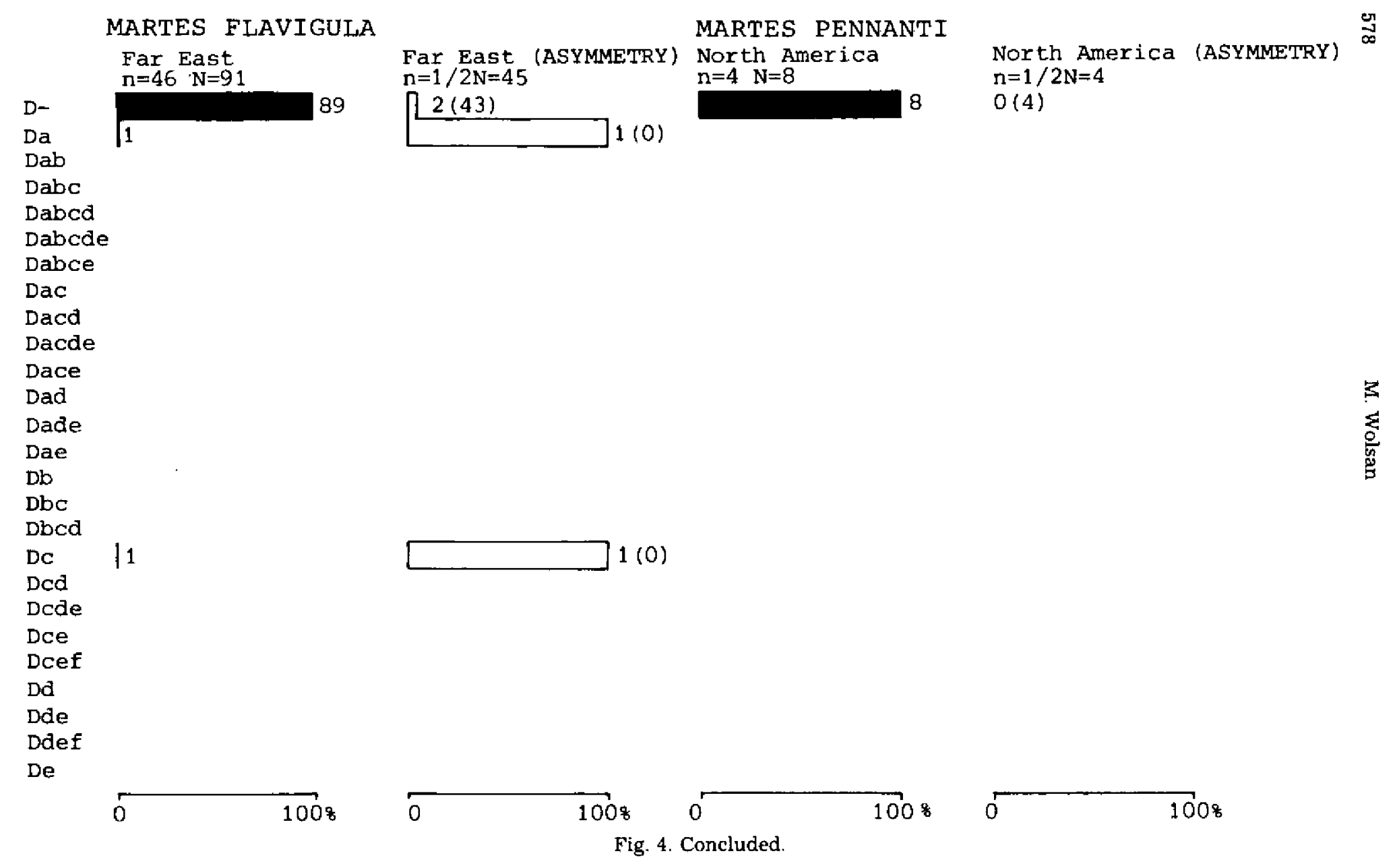



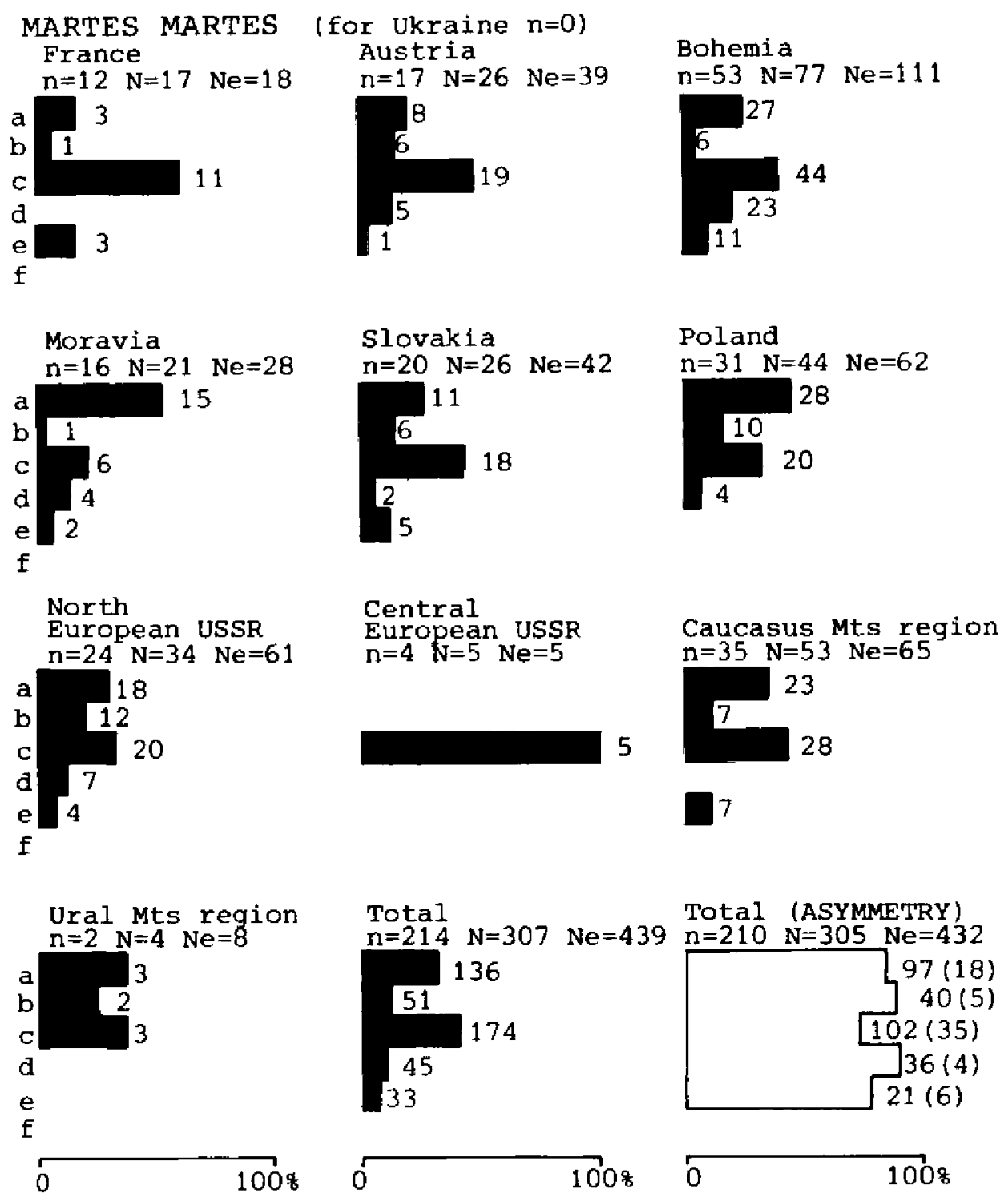

Total (ASYMMETRY)

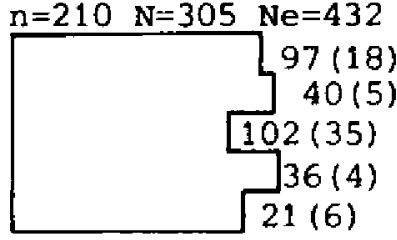

Fig. 5. Frequency distributions and right-left asymmetry of enamel elevations a-f. For solid histograms, the percentage frequency (horizontal scale) is plotted against the corresponding elevation (vertical scale). For open histograms, the percentage of unilateral occurrences in the sum of unilateral and bilateral occurrences (horizontal scale) is plotted against the corresponding elevation (vertical scale). The numbers to the right of the horizontal solid bars show the absolute frequencies of the corresponding elevations. The numbers to the right of the horizontal open bars indicate the absolute frequencies of the unilateral and, in parentheses, bilateral occurrences of the corresponding elevations. Ne, $\mathrm{N}$, and $\mathrm{n}$ are the numbers of scored elevations, teeth, and skulls, respectively. Continued on pp. $580-582$. 


\section{MARTES MARTES $x$ MARTES ZIBELLINA}

Ural Mts region

$n=7 \quad \mathrm{~N}=10 \quad \mathrm{Ne}=16$

a 2

b 2

c 1

e 3

$\mathbf{f}$

\section{MARTES ZIBELLINA}

Ural Mts region $n=9 \quad N=14 \quad \mathrm{Ne}=17$

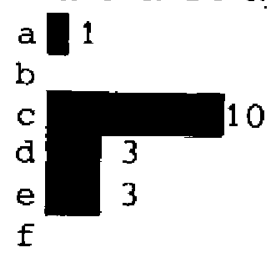

Central Asia

$\mathrm{I}=93 \quad \mathrm{~N}=156 \quad \mathrm{Ne}=207$

$\mathrm{n}=7 \quad \mathrm{~N}=10 \quad \mathrm{Ne}=16$

$O(1)$

$0(1)$
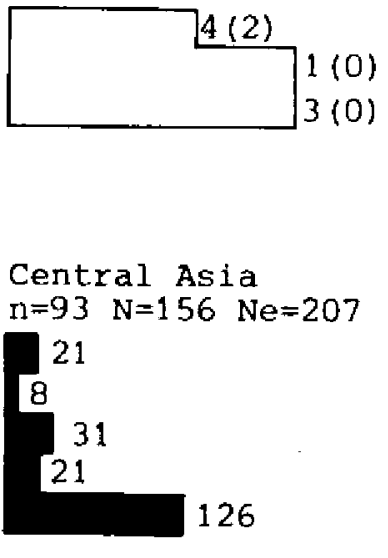

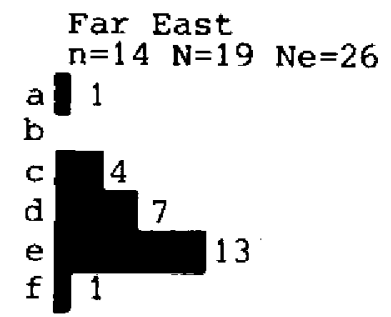

Kamchatka

$\mathrm{n}=116 \mathrm{~N}=199 \mathrm{Ne}=235$

10

1

23

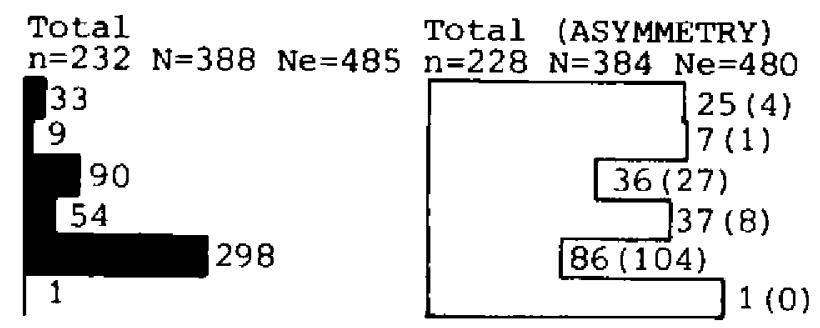

$\underset{n=0}{\text { MARTES MELAMPUS }}$

MARTES AMERICANA

North America North America (ASYMMETRY)

$n=3 \mathrm{~N}=3 \mathrm{Ne}=6 \quad \mathrm{n}=2 \mathrm{~N}=2 \mathrm{Ne}=2$

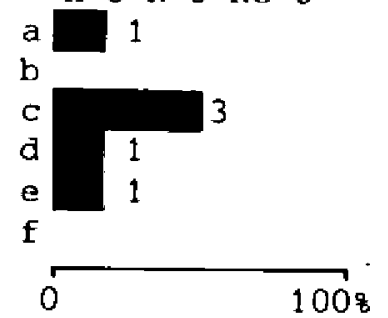

$2(0)$
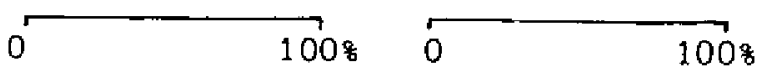

Fig. 5. Continued. 


\section{MARTES FOINA}

$a$
$b$
$c$
$d$

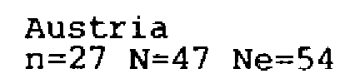

a

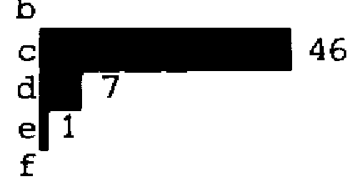

Poland

$\mathrm{n}=11 \mathrm{~N}=19 \mathrm{Ne}=19$

a) 4

$\mathrm{b}$

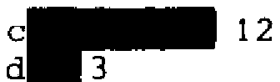

e

$$
\text { Central Asia }
$$
$\mathrm{n}=8 \mathrm{~N}=13 \mathrm{Ne}=13$

a

b

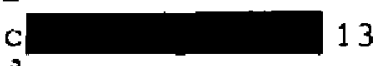

a

e

f
Bohemia

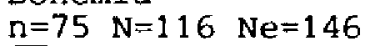

15

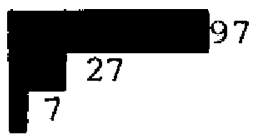

Ukraine

$\mathrm{n}=10 \mathrm{~N}=18 \mathrm{Ne}=20$

2

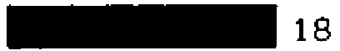

18

Total

$\mathrm{n}=257 \quad \mathrm{~N}=420 \quad \mathrm{Ne}=522$

69

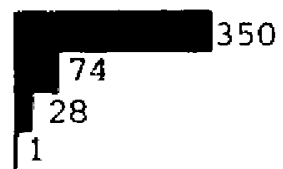

Far East (ASYMMETRY) $\mathrm{n}=2 \mathrm{~N}=2 \quad \mathrm{Ne}=2$

Far East

$\mathrm{n}=2 \quad \mathrm{~N}=2 \quad \mathrm{Ne}=2$

$$
\text { a }
$$

b

c 1

d

e

f

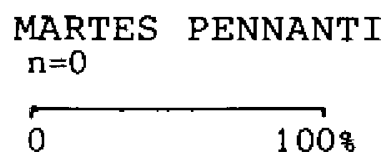

1 (0)

$1(0)$

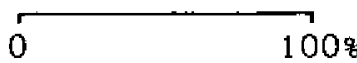

France $\mathrm{n}=32 \mathrm{~N}=55 \mathrm{Ne}=64$

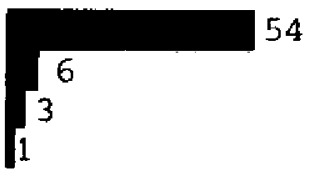

Moravia

$n=66 \quad \mathrm{~N}=103 \quad \mathrm{Ne}=157$

48

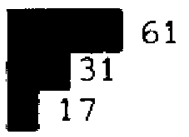

Caucasus Mts region $n=28 \quad \mathrm{~N}=49 \quad \mathrm{Ne}=49$

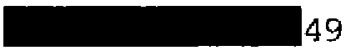

Total (ASXMMETRY)

$n=251 \quad \mathrm{~N}=414 \quad \mathrm{Ne}=516$ 45 (12)

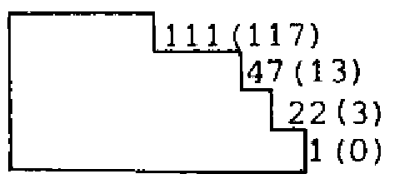

1008

Fig. 5. Continued. 


\section{GENUS MARTES}
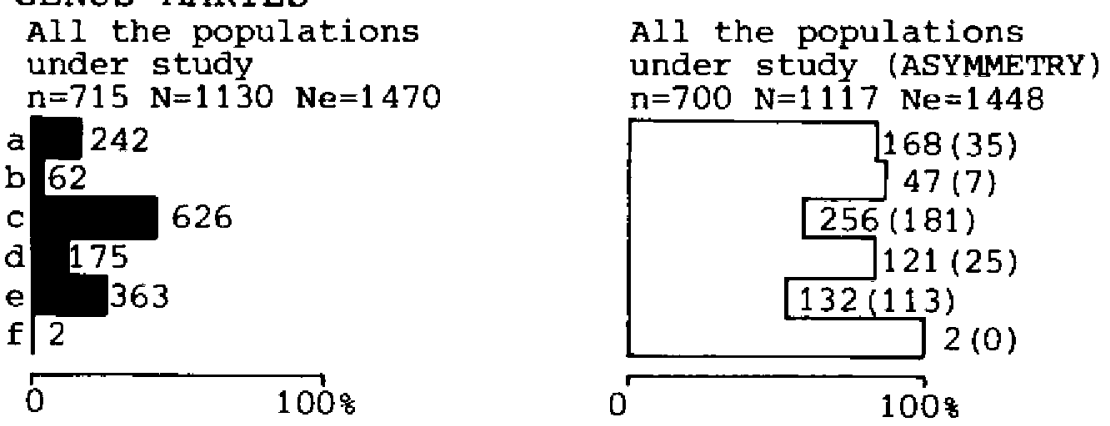

Fig. 5. Concluded.
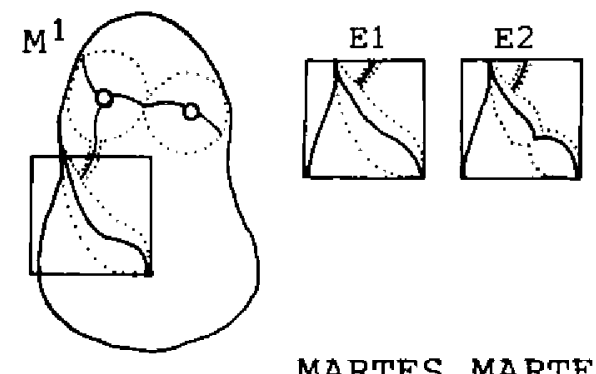

E1

MARTES MARTES

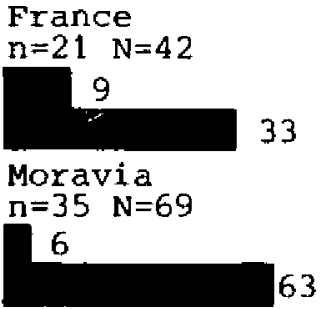

E2

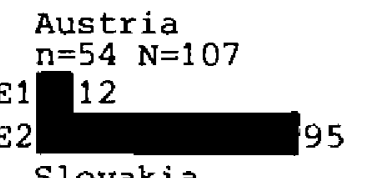

Bohemia

$\mathrm{n}=112 \mathrm{~N}=214$

25

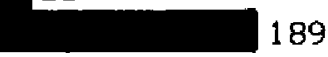

Slovakia

Poland

$\mathrm{n}=40 \quad \mathrm{~N}=78$

$\mathrm{n}=152 \mathrm{~N}=293$

23

$\mathrm{E} 2$

5

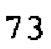

Central Eur. USSR $\mathrm{n}=40 \quad \mathrm{~N}=79$

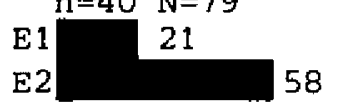

Ural Mts region

$\mathrm{n}=10 \quad \mathrm{~N}=19$
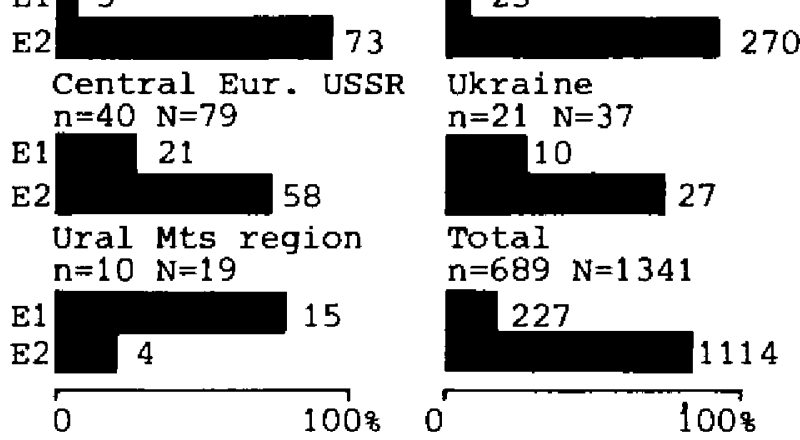

North European USSR

$\mathrm{n}=123 \mathrm{~N}=243$

54

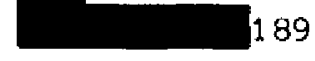

Caucasus Mts region

$\mathrm{n}=81 \mathrm{~N}=160$

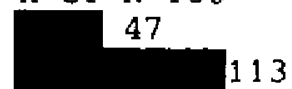

Total (ASYMMETRY)

$n=1 / 2 \mathrm{~N}=652$

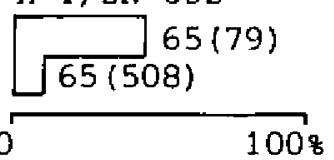

Fig. 6. Diagrams, frequency distributions, and right-left asymmetry of the morphotypes of group E. For explanation see Fig. 1. Continued on pp. 583-584. 
MARTES FOINA

E1

E2

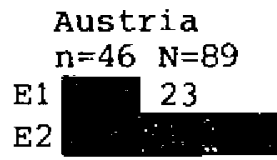

66
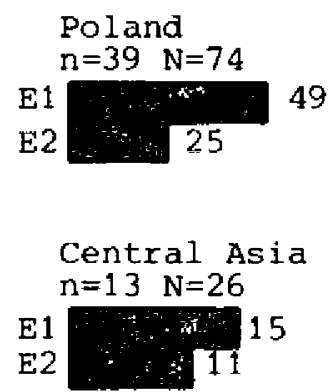

Bohemia

$\mathrm{n}=116 \quad \mathrm{~N}=\mathbf{2 2 4}$
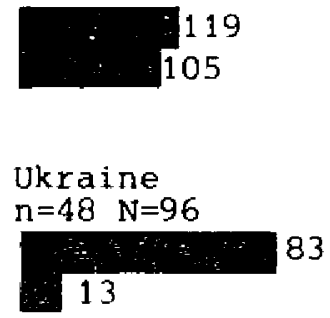

Total $\mathrm{n}=506 \quad \mathrm{~N}=988$

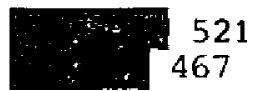

France

$\mathrm{n}=61 \quad \mathrm{~N}=118$

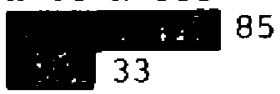

Moravia $n=106 \quad N=209$

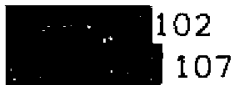

Caucasus Mts region $\mathrm{n}=77 \mathrm{~N}=152$

\section{$\therefore 45$}

107

Total (ASYMMETRY)

$\mathrm{n}=1 / 2 \mathrm{~N}=482$

$88(210)$

$88(184)$

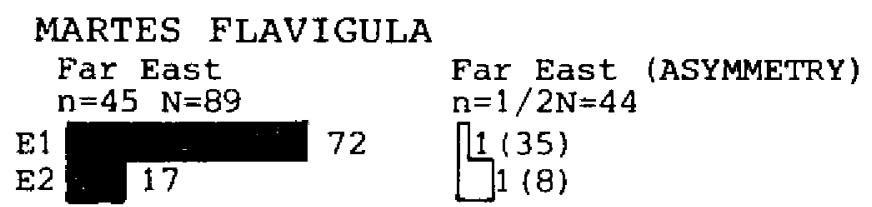

Far East

$n=45 \quad N=89$

E1

E2 17

Far East (ASYMMETRY)

$\mathrm{n}=1 / 2 \mathrm{~N}=44$

$1(35)$

1 (8)

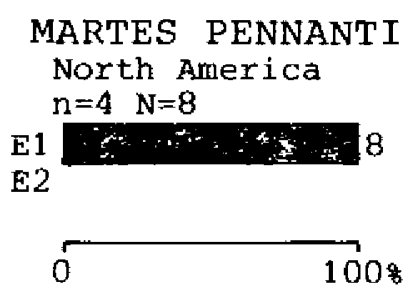

North America (ASYMMETRY) $n=1 / 2 N=4$

$0(4)$

a

1008

100\%

Fig. 6. Concluded. 


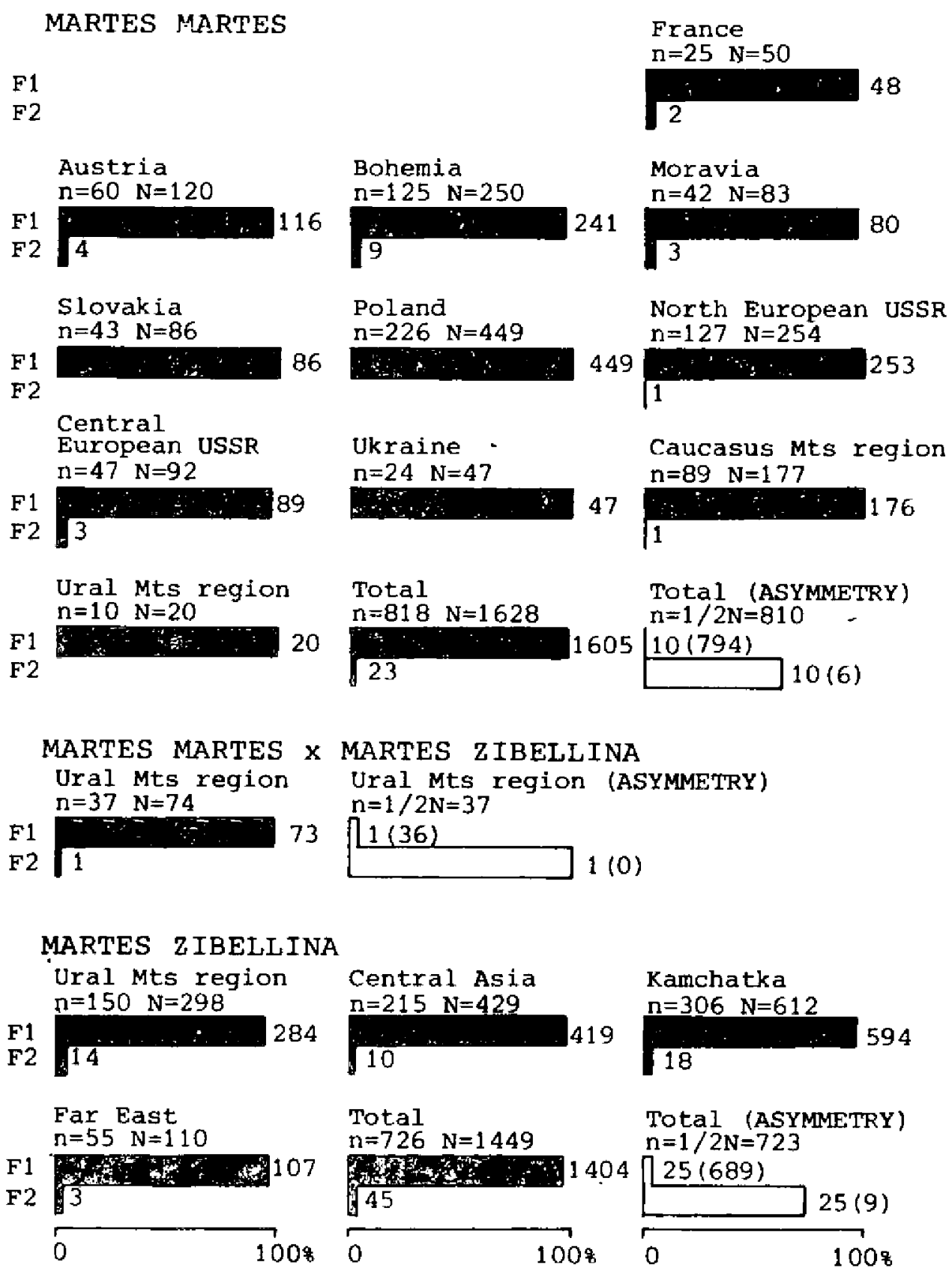

Fig. 7. Frequency distributions and right-left asymmetry of the morphotypes of group $F$. For explanation see Fig. 1. Concluded on p. 586. 


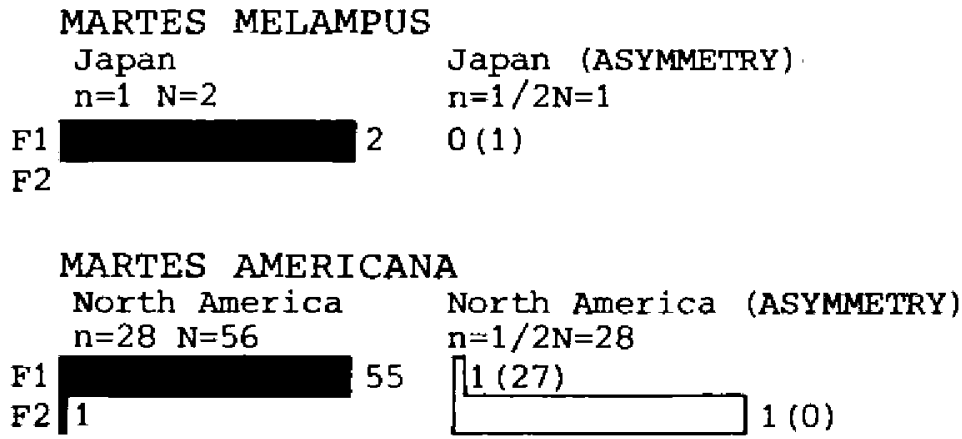

\section{MARTES FOINA}

F1

F2

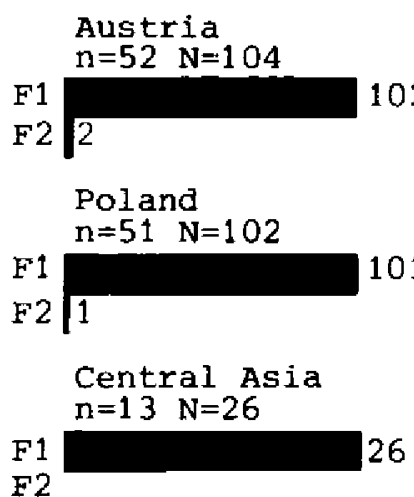

Bohemia

$n=138 \quad \mathrm{~N}=275$

02

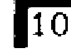

Ukraine $n=54 \quad N=108$ 01 7

Total $\mathrm{n}=576 \mathrm{~N}=1150$

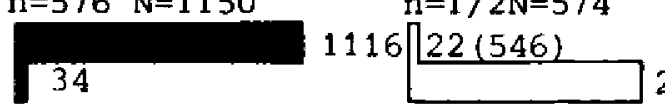

France

$\mathrm{n}=66 \mathrm{~N}=131$ 128 3

Moravia

265 $n=118 \quad N=236$

11

Caucasus Mts region $\mathrm{n}=84 \quad \mathrm{~N}=168$

101

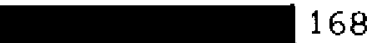

Total (ASYMMETRY)

$\mathrm{n}=1 / 2 \mathrm{~N}=574$

$22(6)$
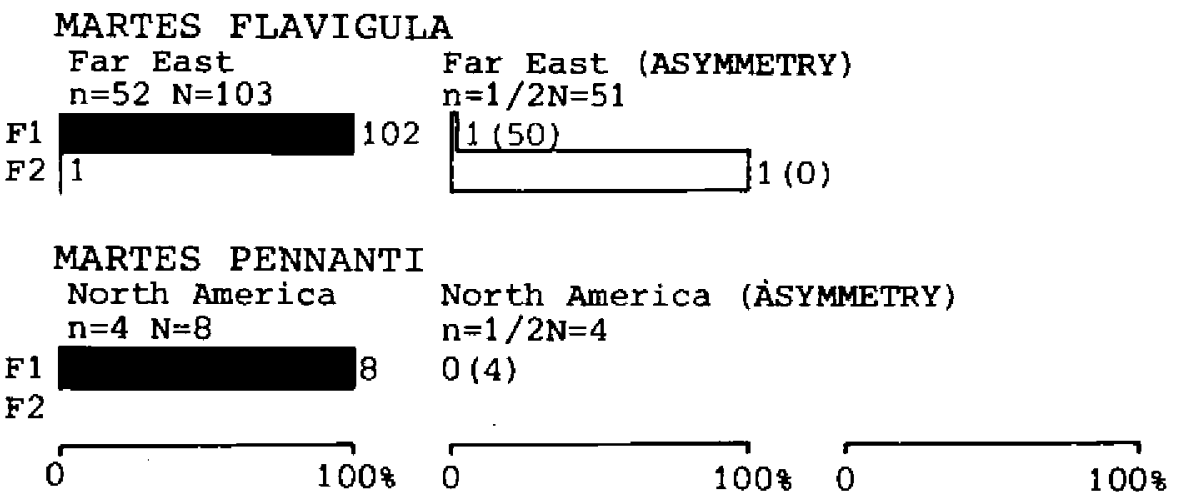

Fig. 7. Concluded. 


\section{MARTES MARTES}

G1

$\mathrm{G} 2$

$$
\text { Austria }
$$$$
\text { G1 }
$$

$=57 \quad \mathrm{~N}=114$

G2 $2+1+3$

Slovakia

$\mathrm{n}=43 \quad \mathrm{~N}=86$

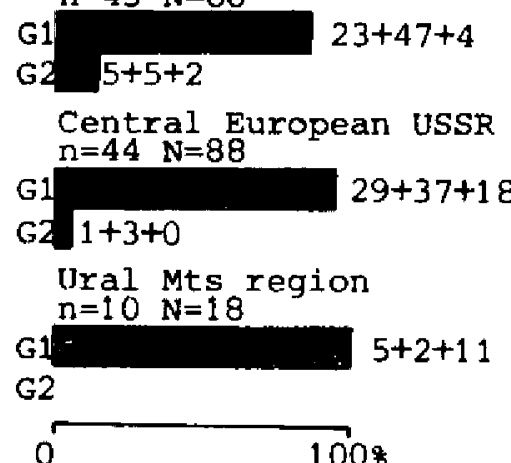

Bohemia (+)

$\begin{array}{ll}\mathrm{n}=123 \mathrm{~N}=245 & 70+142+24 \\ 6+3+0 & \\ \text { Pol and (t) } \\ \mathrm{n}=223 \mathrm{~N}=442 & 172+242+0 \\ 18+10+0 & 10+29+8 \\ \mathrm{nkraine} & \end{array}$

Total (++)

$\underbrace{\substack{n=797 \quad \mathrm{~N}=1577 \\ 45+28+12}}_{0} 476+698+318$

France

$\mathrm{n}=23 \quad \mathrm{~N}=45$

$2+0+1$

$4+2+36$

Moravia $i t$

$\mathrm{n}=40 \quad \mathrm{~N}=79$

$4+0+2$

North European USSR

$\mathrm{n}=123 \mathrm{~N}=242$

$6+6+2 \quad 77+6 " 6+85$

Caucasus Mts region

$\mathrm{n}=87 \mathrm{~N}=171$

$1+0+2$
Total (ASYMMETRY)
$n=1 / 2 \mathrm{~N}=7808+56$
$\frac{39(719)}{4} 39(22)$
$0 \quad 1008$

Fig. 8. Frequency distributions and right-left asymmetry of the morphotypes of group G. For solid histograms, the percentage frequency (horizontal scale) is plotted against the corresponding morphotype (vertical scale). For open histograms, the percentage of unilateral occurrences in the sum of unilateral and bilateral occurrences (horizontal scale) is plotted against the corresponding morphotype (vertical scale). The numbers to the right of the horizontal solid bars show the absolute frequencies of the corresponding morphotypes for females, males, and specimens of undetermined sex, respectively from left to right. The numbers to the right of the horizontal open bars indicate the absolute frequencies of the unilateral and, in parentheses, bilateral occurrences of the corresponding morphotypes. $N$ and $n$ are the numbers of scored teeth and skulls, respectively. Plus signs in parentheses indicate the populations for which statistically significant differences between female and male absolute frequency distributions were discovered by the chi-square test: $(+)$ for $0.001<p<0.05,(++)$ for 
MARTES MARTES $x$ MARTES ZIBELLINA

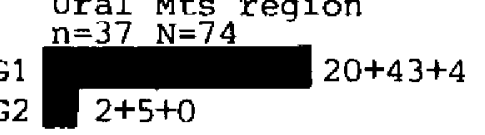

Ural Mts region (ASYMMETRY)

MARTES ZIBELLINA

Ural Mts region

$n=148 \quad N=257$

Central Asia $(+$

$n=225 \quad N=433$

$12+16+29 \quad 87+128+13$

\section{$16+11+8$}

Kamchatka $(+)$

$\mathrm{n}=303 \mathrm{~N}=603$

Far East

$n=54 \quad \mathrm{~N}=108$

G1

$0+3+5$

$24+43+33$

Total (+)

$n=730 \quad N=1401$

$37+36+49$

$263+438+578$

MARTES MELAMPUS

$\mathrm{Japan}$

G1

G2

MARTES AMERICANA

North America

$n=28 \quad N=56$

Japan (ASYMMETRY)
$n=1 / 2 \mathrm{~N}=1$

$n=1 / 2 \mathrm{~N}=1$

$0(1)$

$9+6+35$

Total (ASYMMETRY)

$\mathrm{n}=1 / 2 \mathrm{~N}=677$

$\lceil 57(589)$

North America (ASYMMETRY)

$\mathrm{n}=1 / 2 \mathrm{~N}=28$

G1

$0+0+1$

1 (27)

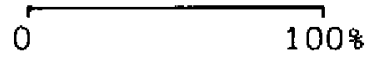


MARTES FOINA

G1

G2

Austria

G1

$n=51 \quad N=102$

G2

$2+9+2$

Pol and

$n=54 \quad \mathrm{~N}=108$

G2 $5+9+0$

Central Asia

G1

$n=13 \quad \mathrm{~N}=26$

G2

MARTES FLAVIGULA

Far East

$n=51 \quad \mathrm{~N}=101$

$\mathrm{G} 2 \widehat{\mathrm{O}+0+1}$

$38+28+34$

MARTES PENNANTI

North America

G1

$\Omega=4 \quad N=8$

$\mathrm{G} 2$

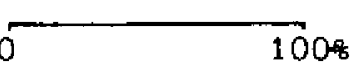

Bohemia (t)

$n=137 \quad \mathrm{~N}=272$

$78+75+42$

$48+18+11$

Ukraine

$\mathrm{n}=53 \mathrm{~N}=104$

$25+26+8$

$25+17+3$

$\begin{array}{ll}\text { Total } & (++) \\ n=550 & \mathrm{~N}=1087\end{array}$

$260+346+237$

$125+82+37$

France

$\mathrm{n}=52 \mathrm{~N}=102$

$6+4+11$

Moravia (t)

$n=113 \quad \mathrm{~N}=223$

$49+81+28$

Caucasus Mts region

$\mathrm{n}=77 \mathrm{~N}=150$

$5+3+1$

Total (ASYMMETRY)

$\mathrm{n}=1 / 2 \mathrm{~N}=537$

$80(377)$

$80(80)$

Far East (ASYMMETRY)

$\mathrm{n}=1 / 2 \mathrm{~N}=50$

1(49)

$1(0)$

North America (ASYMMETRY)

$0(4)$

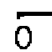

1008

1008 
Recent

Martes

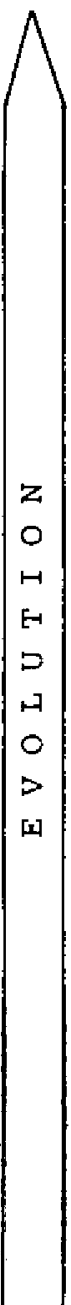

Hypothetical Late Cretaceous/Early Paleogene ancestor of the lineage of Martes
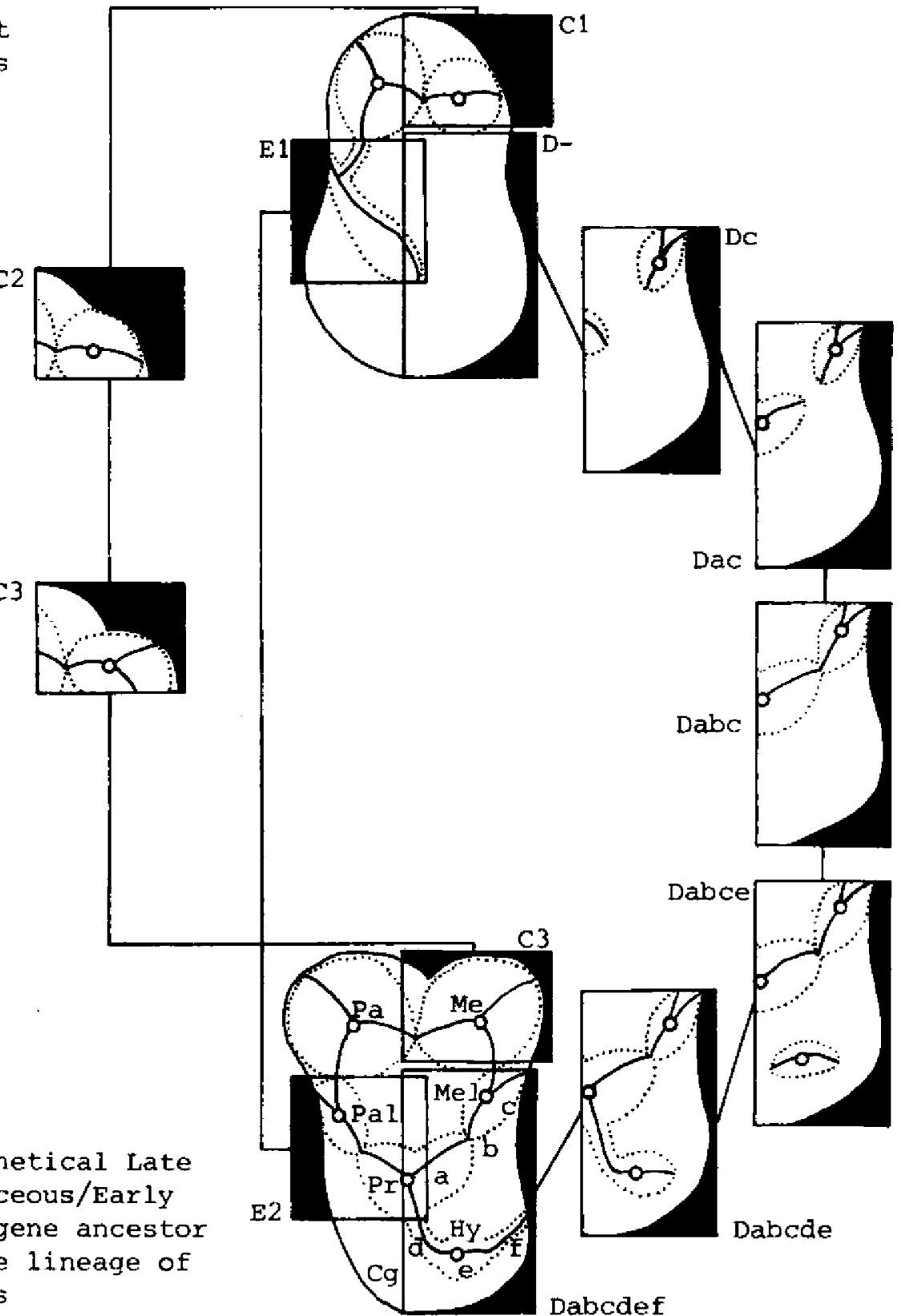

Fig. 9. Hypothetical sequence of the morphological patterns of $\mathrm{M}^{1}$ in the Cenozoic evolution of the lineage of Martes. The corresponding morphotypes are fixed. $\mathrm{Cg}=$ cingulum, $\mathrm{Hy}=$ hypocone, $\mathrm{Me}=$ metacone, $\mathrm{Mel}=$ metaconule, $\mathrm{Pa}=$ paracone, Pal=paraconule, $\mathrm{Pr}=$ protocone; $\mathbf{a}, \mathrm{b}$, and $\mathrm{c}$ indicate, respectively, the anterior, medial, and posterior regions of the protocone-metaconule-posterior cingulum crest, and $d, e$, and $f$ are, respectively, those of the protocone-hypocone-posterior cingulum crest. 


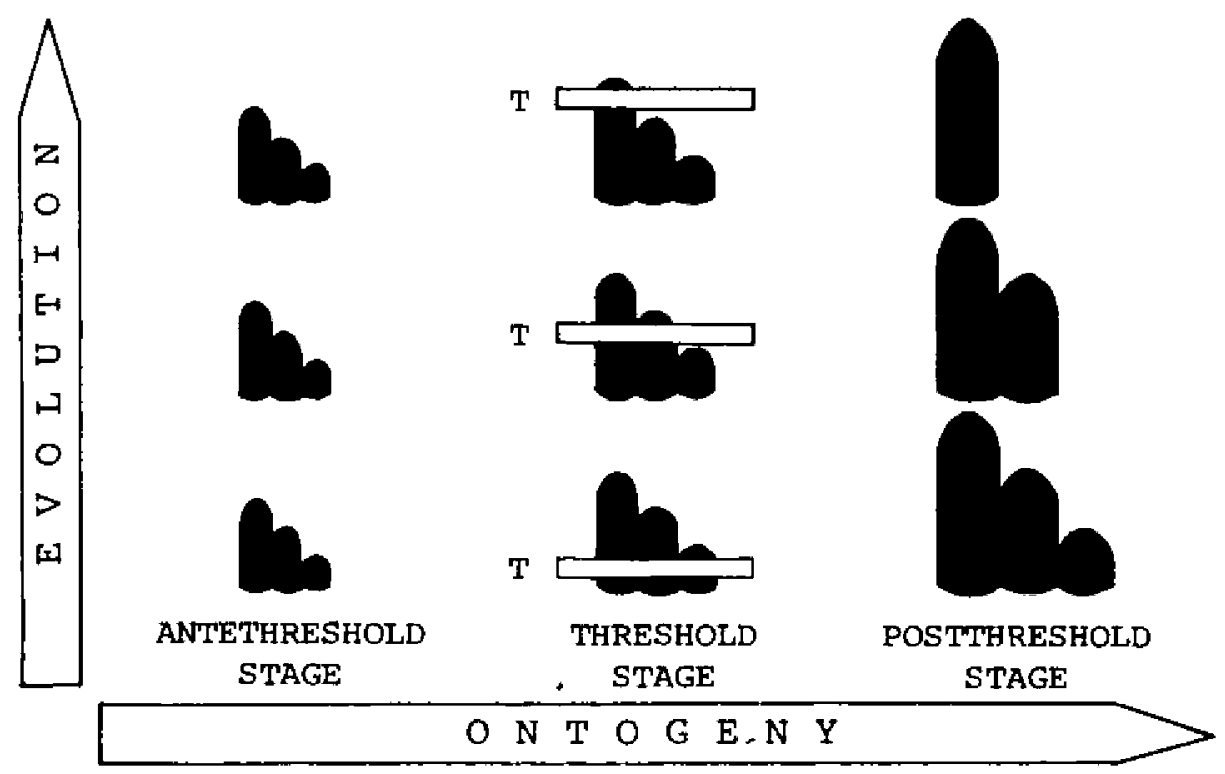

Fig. 10. Model of the genetic control of changes in dental morphology during evolution. Genetic information responsible for the antethreshold morphological pattem is virtually stable. Gradual simplification in the postthreshold pattern of dental morphology results from the upward movement of the threshold ( $\mathrm{T}$ ) and/or the backward movement of the threshold stage which are caused by qualitative changes in a set of other genes than those of the antethreshold pattern. 
Mieczysław WOLSAN

POLIMORFIZM UZĘBIENIA W RODZAJU MARTES (CARNIVORA: MUSTELIDAE) ORAZ JEGO ZNACZENIE EWOLUCYJNE

\section{Streszczenie}

Stosując siedem grup morfotypów (Ryc. $1-4,6-8$ ), opisano polimorfizm $P_{1}^{1}, P_{3}^{3}, P_{4}$ i $\mathrm{M}^{1}$ w 28 wspólczesnych populacjach Martes martes $(\mathrm{n}=828), M$. martes $\times M$. zibellina $(\mathrm{n}=37), M$. zibellina $(\mathrm{n}=749), M$. melampus $(\mathrm{n}=1), M$. americana $(\mathrm{n}=28), M$. foina $(\mathrm{n}=593)$, $M$. flavigula $(\mathrm{n}=53)$ i $M$. pennanti $(\mathrm{n}=4)$. Zarówno gatunki, jak też ich populacje, różniq się jakościowo i ilościowo rozkładami częstości morfotypów (Ryc. 1--8). Statystycznie istotny dymorfizm płciowy w rozkładach częstosci morfotypów $(p<0.05)$ wykazano jedynie dla polimorfizmu G (Ryc. 8). Morfotypy występowaly dwustronnie lub jednostronnie, przy czym im dany morfotyp był rzadszy w populacji, tym czessciej pojawial się tylko $z$ jednej strony ciała (Ryc. 1-8).

Cechy morfologiczne uzębienia związane z polimorfizmem $A-G$ odznaczają się stalym miejscem występowania i zależnym od tego miejsca ksztaltem. Badane gatunki, zwłaszcza w obrębie podrodzaju Martes, wykazuja takie same wzorce zmienności. Zmiennosé geograficzna rozkładów częstosci morfotypów ma często charakter klinalny. W populacji M. martes $\times M$. zibellina morfotypy osiągaja na ogół częstosci pośrednie w porównaniu z odpowiadającymi im wartosciami dla sympatrycznych populacji $M$. martes i $M$. zibellina. Wymienione własności analizowanych cech wskazuja, że są one dziedziczone. Częste występowanie asymetryczne morfotypów sugeruje, że oprocz czynnikow genetycznych, także czynniki srodowiskowe wpływaja na ostateczna postać badanych cech.

Własnosci cech morfologicznych związanych z polimorfizmem A-G spelniają warunki cech progowych. Działanie mechanizmu progowego przejawia się we wczesnych etapach ontogenezy i polega na zatrzymywaniu rozwoju tych elementow danej struktury, które nie osiągnęły w krytycznej fazie progowej wystarczających (progowych) rozmiarów. Im dany element jest mniejszy w fazie działania mechanizmu progowego, tym większe jest prawdopodobieństwo jego zaniknięcia w dalszym rozwoju. Tak więc, im częściej występuje on w populacji dorostych osobnik6w, tym bardziej jest prawdopodobne to, że wykazywal większe rozmiary w fazie progowej. A zatem, wydaje sie możliwym odtworzenie wysoce prawdopodobnego przedprogowego wyglądu badanych okolic uzębienia $w$ oparciu o morfologię tych okolic na całkowicie rozwiniętych zębach, a także znajomosc rozkładów częstosci opisanych morfotypów. I tak, przedprogowy wygląd tych okolic odpowiadałby morfotypom A4, B5, C3, Dabcdef, E2, F1 i G1 (Ryc. 1-4, 6-8). Polimorfizm A- $G$ byłby więc spowodowany różnicami w rozmiarach elementów składowych danego wzorca morfologicznego, różnicami w wysokości progu, oraz różnicami w umiejscowieniu fazy progowej $w$ ontogenezie.

Ponieważ analizowane cechy są najwyraźniej kontrolowane genetycznie, istnieją więc dwa możliwe wythumaczenia ich obecności u wspólczesnych kun: (1) cechy te wywodza się od ssaków lożyskowych z późnej kredy i wczesnego paleogenu, (2) cechy te pojawily się w wyniku stosunkowo niedawnych mutacji. Polimorfizm A-G występuje u wszystkich wspólczesnych gatunkow rodzaju Martes, co sugeruje, ze jest on odziedziczony po wspólnym ich przodku. Swiadcza o tym również dane paleontologiczne. U kun wspólczesnych i kopalnych z czwartorzędu przeważaja morfotypy A1-A3, B1-B3 $\left(\mathrm{P}_{3}\right), \mathrm{B} 3-\mathrm{B} 5$ $\left(\mathrm{P}_{4}\right), \mathrm{Cl}-\mathrm{C} 3, \mathrm{D}-, \mathrm{E} 1$ lub E2, F1 i G1. Zachowane szczątki kun z neogenu sugeruja, że do najczęstszych morfotypow należaly wtedy A3, B2 i B3 $\left(\mathrm{P}_{3}\right)$, B4 i B5 $\left(\mathrm{P}_{4}\right), \mathrm{C3}$, Dabc i Dac, E2, F1 i G1. Wczesnomioceński gatunek Paragale huerzeleri, jeden z najwcześniej- 
szych znanych lasicowatych, nawiązuje wyglądem $\mathrm{M}^{1}$ do morfotypu Dabcdef. Zęby niektórych lożyskowców z późnej kredy i wczesnego paleogenu uderzająco przypominaja najbardziej prawdopodobny wygląd odpowiadających im zębow wspotczesnych kun w fazie przedprogowej. Tak więc hipoteza, zakładająca, że cechy morfologiczne związane z polimorfizmem A-G są homologiczne (plezjomorficzne) w stosunku do odpowiadajacych im cech uzębienia wczesnych ssaków łożyskowych, jest dużo bardziej prawdopodobna aniżeli hipoteza, sugerująca, że chodzi tu o cechy analogiczne (apomorficzne).

Dane paleontologiczne wskazuja, że badane cechy były polimorficzne także u wymarlych gatunków rodzaju Martes, co najprawdopodobniej mialo też miejsce u ich przodków, wliczając $w$ to wczesne lożyskowce. Swiadczyłoby to o istnieniu u tych ostatnich takich samych lub podobnych mechanizmow ontogenetycznych, jak u wspólczesnych kun. A zatem, informacja genetyczna odpowiedzialna za przedprogowy wzorzec morfologiczny badanych okolic uzębienia nie uleglaby istotnym zmianom $w$ trakcie ewolucji linii filetycznej Martes w kenozoiku. Ogolna tendencja do upraszczania wzorca morfologicznego uzębienia $w$ linii kun byłaby więc wynikiem stopniowych zmian w częstosciach morfotypów w kierunku najprostszych morfologicznie, tj. od A4 poprzez A3 i A2 do Al, od B5 poprzez B4, B3 i B2 do B1, od C3 poprzez C2 do C1, od Dabedef poprzez Dabcde, Dabce, Dabc, Dac i Dc do D- (Ryc. 9), od E2 do E1, od F1 do F2, oraz od G1 do G2. Stopniowe zmiany częstości morfotypów bylyby następstwem progresywnego podnoszenia sie poziomu progowego lub (i) cofania się fazy progowej w ontogenezie (Ryc. 10). Przesunięcia te spowodowane by były jakosciowymi zmianami w zestawie genów progowych, innych niż geny przedprogowego wzorca morfologicznego. 